\title{
10. CRETACEOUS AND EARLY TERTIARY FORAMINIFERS FROM DEEP SEA DRILLING PROJECT LEG 62 SITES IN THE CENTRAL PACIFIC ${ }^{1}$
}

\author{
Anne Boersma, Lamont-Doherty Geological Observatory of Columbia University, Palisades, New York
}

\section{INTRODUCTION}

During DSDP Leg 62, foraminifers were recovered from four holes in the central North Pacific. At Site 463 , in the Mid-Pacific Mountains $\left(21^{\circ} 21^{\prime} \mathrm{N}, 174^{\circ}\right.$ $40^{\prime} \mathrm{E}$; water depth $2525 \mathrm{~m}$ ), the Cretaceous section included Aptian-Albian to Maastrichtian sediments. Paleogene faunas occurred in a mixed zone in three cores from strata unconformably overlying the Cretaceous. Recovery was very poor at Site $464\left(39^{\circ} 51^{\prime} \mathrm{N}, 173^{\circ}\right.$ $53^{\prime} \mathrm{E}$; water depth $4637 \mathrm{~m}$ ), on the northern flank of Hess Rise. Twenty-four cores of Cretaceous material encompassed the Cenomanian-Albian. Site 465 (Hole $465 \mathrm{~A})$ on southern Hess Rise $\left(33^{\circ} 49^{\prime} \mathrm{N}, 178^{\circ} 55^{\prime} \mathrm{E}\right)$ was drilled at a depth of 2161 meters. The Cretaceous section includes upper Albian to uppermost Maastrichtian. The Cretaceous/Tertiary boundary was recovered in Hole $465 \mathrm{~A}$, and the combined Paleocene sections from both sites spanned all zones of the Paleocene. A mixed zone of Paleogene sediments overlies the Paleocene at Site 465 . Because of the abundance of chert, only core catchers were recovered in many instances. Poor recovery characterized the Cretaceous section also at Site 466, on southern Hess Rise $\left(34^{\circ} 11^{\prime} \mathrm{N}, 179^{\circ} 15^{\prime} \mathrm{E}\right.$; water depth of $2665 \mathrm{~m}$ ). The Cretaceous section includes 24 cores, of which half contain only core catchers; only the Campanian was successfully cored. Four overlying cores contain mixed Paleogene and Cretaceous materials, thus representing the commonly occurring Paleogene "mixed zone" of the central Pacific (Table 1; Figs. 1 and 2).

Both planktonic and benthic foraminifers were present in nearly every sample younger than Aptian. Preservation varied from generally poor in most Albian samples at each site to very good in most of the Campanian-Maastrichtian section. Paleogene sequences were generally well preserved, except in the mixed zone, where dissolution and recrystallization were common.

\section{METHODS}

Cretaceous planktonic foraminifers were zoned according to the zonation and time scale of van Hinte (1976). Faunas were surveyed, selected species were identified, and relative abundances of those species are tabulated in Figures 3 and 4. Because the author is not a specialist in Cretaceous planktonics, not all species could be identified; faunal lists, therefore, are not inclusive.

Paleogene planktonic foraminifers were zoned according to the zonation and time scale of Hardenbol and Berggren (1978). Relative abundances of Paleocene species are tabulated in Figure 5.

\footnotetext{
${ }^{1}$ Initial Reports of the Deep Sea Drilling Project, Volume 62.
}

Table 1. Geographic position of DSDP Leg 62 sites in the central Pacific today.

\begin{tabular}{|c|c|c|c|c|}
\hline Leg & Site & Latitude & Longitude & $\begin{array}{c}\text { Water } \\
\text { Depth } \\
\text { (m) }\end{array}$ \\
\hline 6 & 47 & $32^{\circ} 26^{\prime} \mathrm{N}$ & $157^{\circ} 42^{\prime} \mathrm{E}$ & 2689 \\
\hline 6 & 45 & $25^{\circ} 15^{\prime} \mathrm{N}$ & $198^{\circ} 30^{\prime} \mathrm{E}$ & 4508 \\
\hline 6 & 44 & $19^{\circ} 18^{\prime} \mathrm{N}$ & $169^{\circ} 00^{\prime} \mathrm{E}$ & 1478 \\
\hline 32 & 305 & $32^{\circ} 13^{\prime} \mathrm{N}$ & $157^{\circ} 51^{\prime} \mathrm{E}$ & 2903 \\
\hline 32 & 310 & $36^{\circ} 52^{\prime} \mathrm{N}$ & $176^{\circ} 54^{\prime} \mathrm{E}$ & 3516 \\
\hline 32 & 313 & $20^{\circ} 10^{\prime} \mathrm{N}$ & $170^{\circ} 57^{\prime} \mathrm{E}$ & 3484 \\
\hline 17 & 171 & $19^{\circ} 07^{\prime} \mathrm{N}$ & $169^{\circ} 27^{\prime} \mathrm{E}$ & 2295 \\
\hline 20 & 200 & $12^{\circ} 50^{\prime} \mathrm{N}$ & $156^{\circ} 46^{\prime} \mathrm{E}$ & 1879 \\
\hline 20 & 202 & $12^{\circ} 48^{\prime} \mathrm{N}$ & $156^{\circ} 57^{\prime} \mathrm{E}$ & 1515 \\
\hline 30 & 288 & $5^{\circ} 58^{\prime} \mathrm{N}$ & $161^{\circ} 49^{\prime} \mathrm{E}$ & 3000 \\
\hline 30 & 289 & $0^{\circ} 29^{\prime} \mathrm{N}$ & $158^{\circ} 30^{\prime} \mathrm{E}$ & 2206 \\
\hline 6 & 51 & $33^{\circ} 28^{\prime} \mathrm{N}$ & $153^{\circ} 24^{\prime} \mathrm{E}$ & 5981 \\
\hline 17 & 167 & $7^{\circ} 04^{\prime} \mathrm{N}$ & $176^{\circ} 49^{\prime} \mathrm{E}$ & 3176 \\
\hline 20 & 199 & $13^{\circ} 30^{\prime} \mathrm{N}$ & $156^{\circ} 10^{\prime} \mathrm{E}$ & 6100 \\
\hline 62 & 463 & $21^{\circ} 21^{\prime} \mathrm{N}$ & $174^{\circ} 40^{\prime} \mathrm{E}$ & 2525 \\
\hline 62 & 464 & $39^{\circ} 51^{\prime} \mathrm{N}$ & $173^{\circ} 53^{\prime} \mathrm{E}$ & 4637 \\
\hline 62 & 465 & $33^{\circ} 49^{\prime} \mathrm{N}$ & $178^{\circ} 55^{\prime} \mathrm{E}$ & 2161 \\
\hline 62 & 466 & $34^{\circ} 11^{\prime} \mathrm{N}$ & $179^{\circ} 15^{\prime} \mathrm{E}$ & 2665 \\
\hline
\end{tabular}

\section{BIOSTRATIGRAPHY}

\section{Site 463}

Site 463 was continuously cored, and sediments were recovered from the Aptian-Albian to the Maastrichtian. Significant hiatuses include the Coniacian-Campanian, and the latest Maastrichtian.

\section{Preservation}

No foraminifers were found in samples below Core 66 , presumably because of the very poor preservation of the material. Late Aptian-Albian faunas were only occasionally preserved; foraminifers are uncommon in the radiolarian oozes. Recognizable foraminifers are tiny and recrystallized. Middle to late Albian (Cores 55-48) faunas are slightly better preserved, but still recrystallized, and apertures are often obscured. Preservation improves in the Cenomanian (Cores 46-40), although intense dissolution is present in Core 43. Preservation is better in the Turonian, although foraminifers are very rare in some intervals (Cores 36 and 37). Moderate preservation characterizes most of the upper Turonian and Coniacian, until in Core 30 foraminifers are entirely recrystallized and cemented together. Campanian sediments are generally well-preserved, except for intervals of moderate to intense dissolution accompanied by chert in Cores $24,23,22$, and one section of 21 . In some 


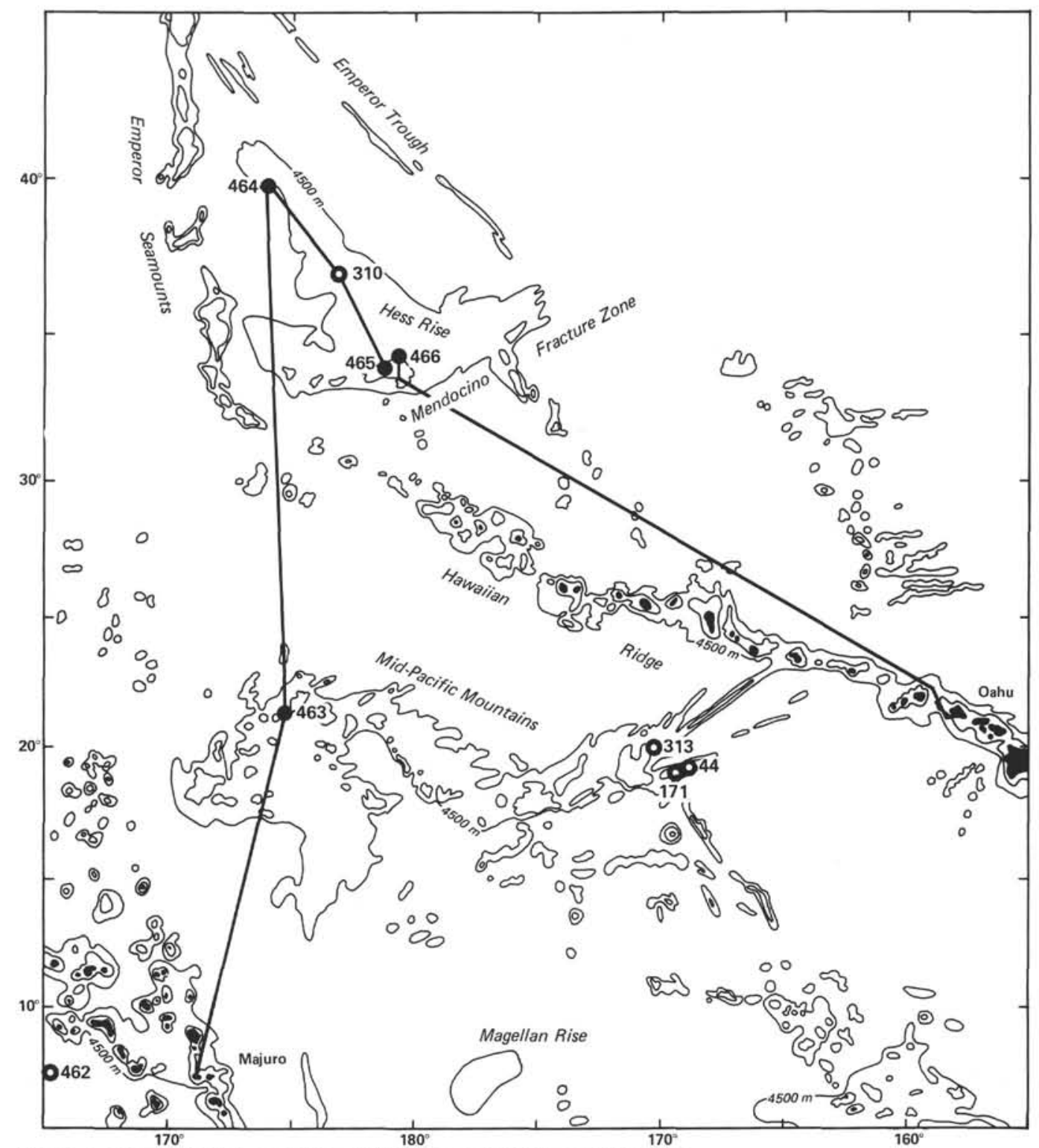

Figure 1. Locations of sites drilled on DSDP Leg 62 in the central Pacific.

faunas, most of the large specimens have been removed by dissolution. Good preservation characterizes the Maastrichtian, except where dissolution has altered faunas in sections of Cores 18,17, 16, 12,11, and 9. Recrystallization of foraminifers occur in two isolated instances in Core 10 and in one section of Core 13.

\section{Foraminifer Faunas}

Aptian-Albian faunas $(66-2$ to $53, \mathrm{CC})$ have only been roughly zoned, since the poor preservation and infrequent faunas make zonal assignation difficult. The co-occurrence of Ticinella bejaouaensis and Hedbergella planispira in Cores 64 and 65 suggests that the samples are located in the uppermost $T$. bejaouaensis Zone and may be Albian. The presence of Ticinella primula in 56,CC and Ticinella breggiensis in 53,CC suggests subdivision of this interval into two middle $\mathrm{Al}-$ bian zones, but faunas are not well enough preserved.
Slightly more-diverse faunas allow recognition of the Rotalipora ticinensis-Planomalina buxtorfi Zone (52 to $50, \mathrm{CC}$ ) by the overlap of the nominate taxa. Ticinella species become larger and more diverse in this zone, and Planomalina buxtorfi is large and abundant at one level.

The first appearance of Rotalipora apenninica, accompanied by Rotalipora evoluta, before the appearance of Rotalipora gandolfi, despite the absence of $P$. buxtorfi, suggests that Cores $49, \mathrm{CC}$ to $48-2$ belong to the latest Albian P. buxtorfi-R. apenninica Zone. Rotalipora apenninica and Praeglobotruncana stephani are common along with $H$. planispira and Hedbergella delrioensis, but Ticinella spp. are less frequent. Clavihedbergella was not seen; Shackoina occurs only in 48,CC.

The first appearance of Rotalipora gandolfi (48-1) marks the base of the Rotalipora gandolfi-Rotalipora greenhornensis Zone (48-1 to 44,CC). Rotaliporids, $P$. stephani and the hedbergellids occur commonly. The 

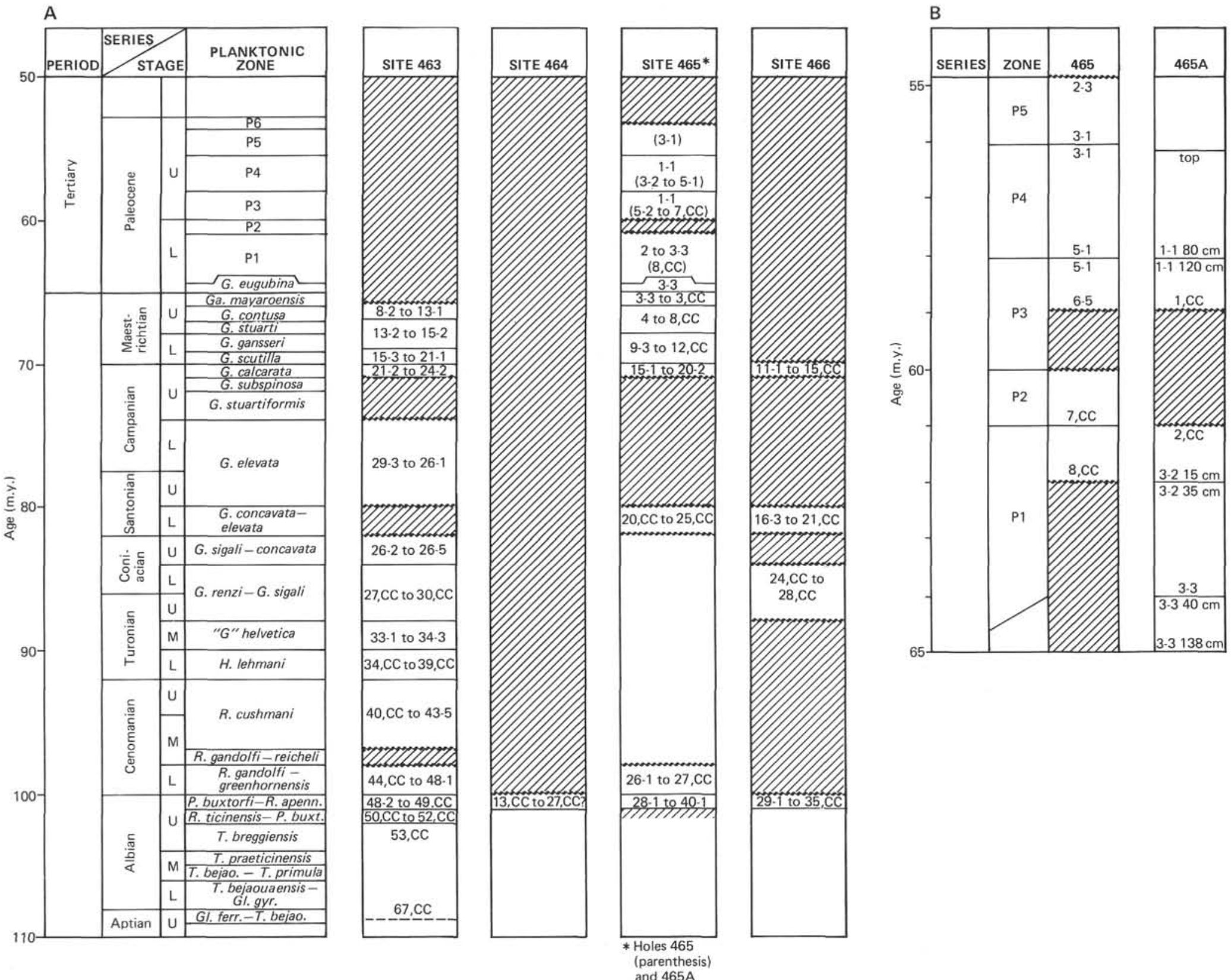

Figure 2. Biostratigraphic summary of Leg 62 sites according to planktonic foraminifers. Planktonic-foraminifer zonation and time scale for the Cretaceous by van Hinte (1976); Paleogene time scale, by Hardenbol and Berggren (1978). Core levels within a zone shown beside the appropriate zone; hiatuses are hachured. 
A

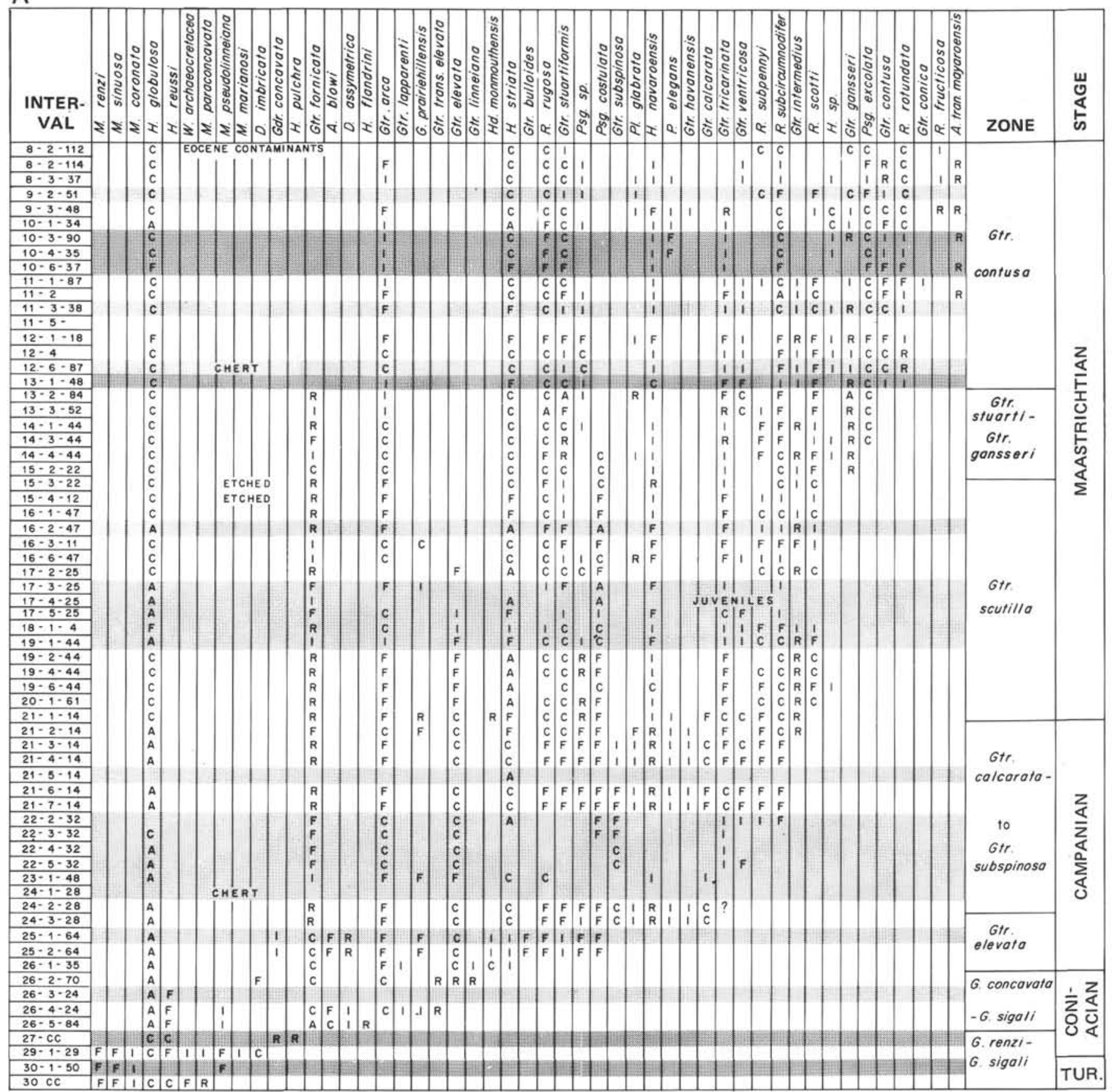

Figure 3. Relative abundances of selected planktonic foraminifer species at Site 463 in the Mid-Pacific Mountains. Recrystallization is indicated by darker banding; levels of significant dissolution by the lighter bands. Levels with chert, etched foraminifers, anomalously small samples, or samples containing only juveniles are indicated. Symbols: A, abundant; C, common; F, frequent; I, infrequent; $R$, rare. Time scale follows van Hinte (1976).

appearance of $R$. cushmani in 43-5 marks the beginning of that Zone (43-5 to $40, C C)$. Rotaliporids are common through this interval, but only three or four species occur in any sample. Praeglobotruncana stephani is common along with $H$. delrioensis and other hedbergellids. Heterohelix reussi and Globigerinelloides caseyi first occur in this zone.

The presence of Whiteinella aprica and abundant, large globigeriniform planktonics typify the Hedber- gella lehmani Zone (39 to $34, \mathrm{CC})$. Heterohelix globulosa, Dicarinella spp., and Praeglobotruncana praehelvetica first occur in these faunas, which are dominated by the whiteinellids. The appearance of Praeglobotruncana helvetica defines the $P$. helvetica Zone $(43, \mathrm{CC}$ to 43-1), which also contains the first marginotruncanids at this site. Accompanying some large heterohelicids are Whiteinella archaeocretacea and, commonly, $H$. planispira. 
B

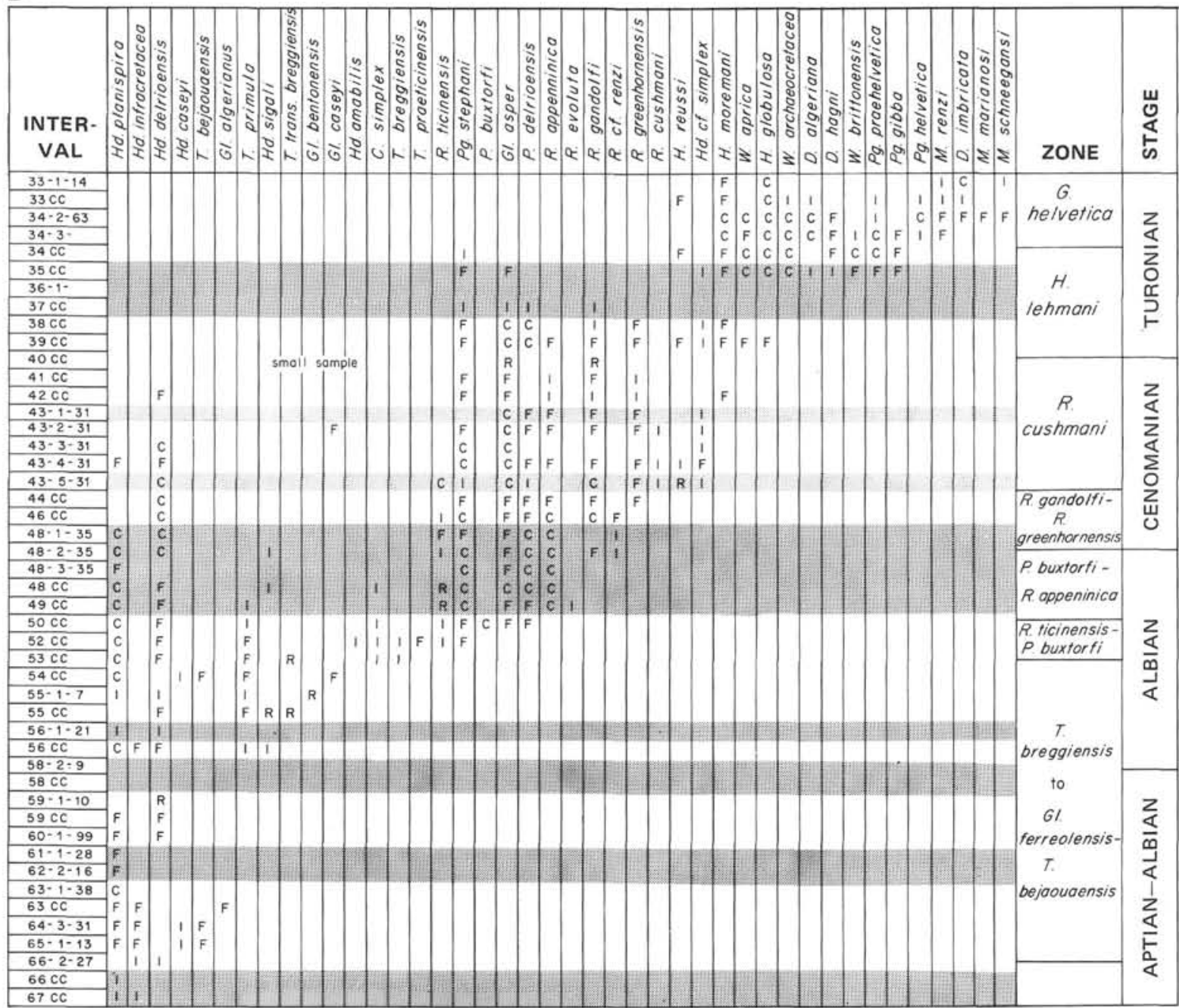

Figure 3. (Continued).

Poor preservation has altered the faunas of the Globotruncana renzi-Globotrunana sigali Zone (30,CC to 26-5), which contains $D$. concavata only at its top. The last of the whiteinellids occur in the base of this zone. In Sample 27,CC, Guembelitria sp. was found. The Globotruncana concavata-Gtr. elevata Zone (26-5 to 26-1) contains Dicarinella assymetrica (formerly Gtr. concavata carinata), Globotruncana fornicata, Globotruncana arca, Globotruncana elevata, and the last $H$. reussi.

The disappearance of the $D$. concavata group, but the continuing presence of Globotruncana elevata, before the evolution of Pseudoguembelina costulata, marks the lower Globotruncana elevata Zone (26-1 to 24-3). The immediate appearance of Pseudoguembelina costulata above suggests the middle Gtr. elevata Zone. Rugoglobigerina rugosa, Globotruncana stuartiformis, and Hedbergella monmouthensis all appear in this interval. This relatively short Gtr. elevata Zone is followed by a long interval containing both Globotruncana subspinosa and Gtr. calcarata, thus defining the Gtr. cal- carata Zone, called here the Gtr. calcarata to Gtr. subspinosa interval, as some of the Gtr. calcarata may be out of place. However, because the transition from Gtr. elevata to Gtr. subspinosa was not seen, and because Gtr. ventricosa, Gtr. tricarinata and Rugotruncana subcircumnodifer all appear in this middle of this interval, this may be an extended Gtr. calcarata Zone. Globotruncana fornicata is less abundant in this zone than in the preceeding ones. Both Gtr. tricarinata and the rugotruncanids become more abundant at the top of this zone. Globotruncana calcarata is well developed; many individuals show a tendency to large, flaring chambers and wide, open umbilical regions. Gublerina, Shack$o i n a$, and $R$. scotti all appear in this zone.

The Globotruncana scutilla Zone (21-1 to 15-2) is marked by the absence of Gtr. calcarata, the continuing presence of Gtr. tricarinata, and abundant rugotruncanids, especially $R$. subpennyi, Globotruncana intermedia, and Gtr. fornicata, before the appearance of Globotruncana gansseri. Globotruncana stuartiformis and $R$. subcircumnodifer are among the most common 


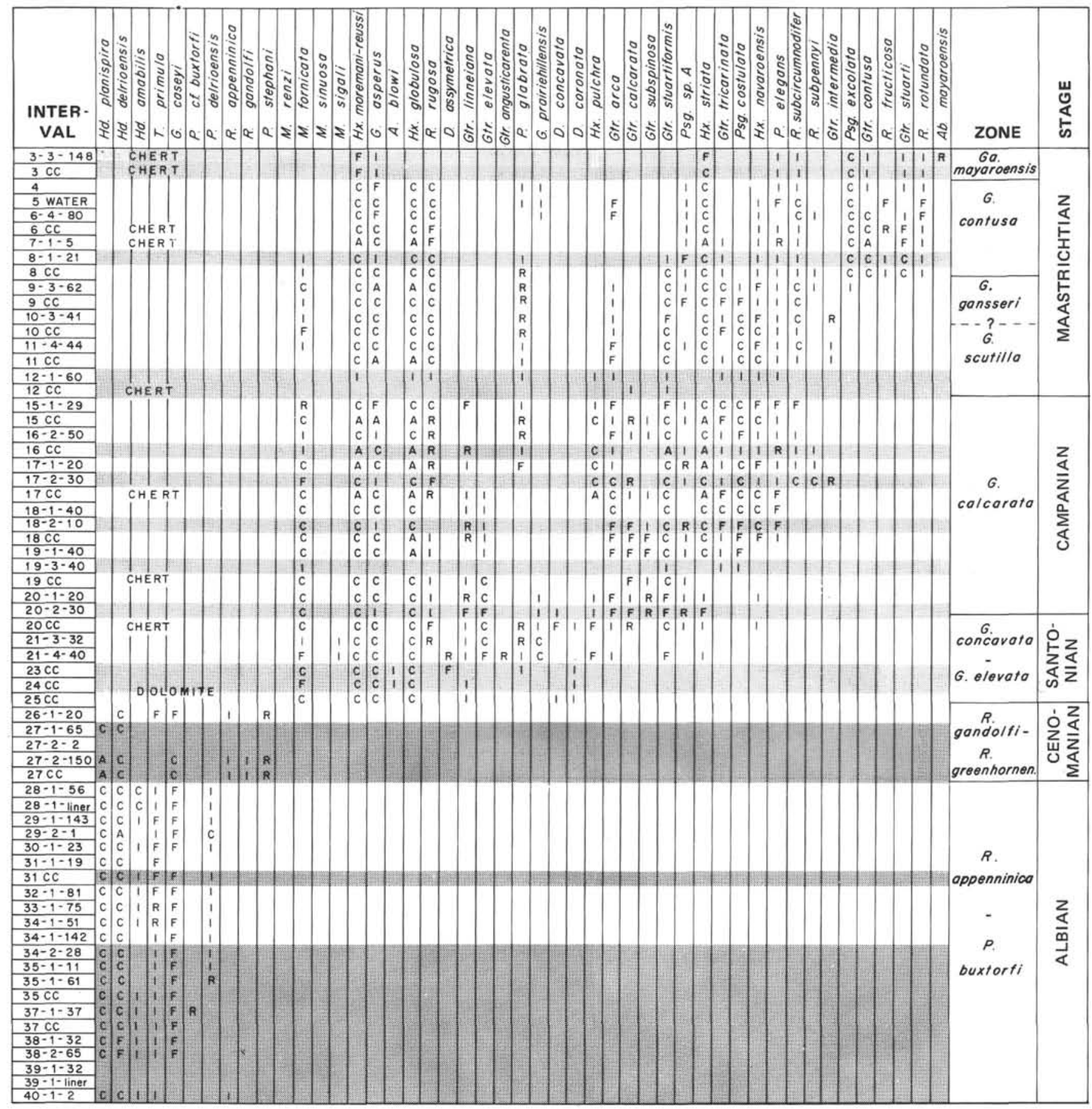

Figure 4. Relative abundances of selected planktonic foraminifer species at Site 465 on Hess Rise. Recrystallization is indicated by the darker bands; dissolution by the light bands. Levels with chert, dolomite, etching, etc. are indicated on the diagram. Symbols as in Figure 3.

elements in these faunas, followed in abundance by Gtr. arca and the heterohelicids. Heterohelix striata and Psg. costulata are particularly abundant at some levels.

The first appearance of the nominate taxon marks the base of the Gtr. gansseri Zone, which is here combined with the Gtr. stuarti Zone, as they have not been differentiated. Pseudoguembelina costulata is replaced by Psg. excolata (14-3) low in the zone, an event associated with the Gtr. gansseri Zone. Globotruncana gansseri is generally rare, except for one level at the top of this interval (13-2). Rugotruncanids become less abundant than below, as do Gtr. fornicata and Gtr. tricarinata. Both $R$. rugosa and Gtr. stuartiformis become particularly abundant at the top of this zone.

The Globotruncana contusa Zone (13-1 to 8-2) is marked by the first appearance of the nominate taxon as well as Rugoglobigerina rotundata. Racemiguembelina fructicosa appears higher in the zone (19-3), accompanied by forms seemingly transitional to Abathomphalus mayaroensis. Rugotruncanids, $R$. rugosa, $R$. ro- 


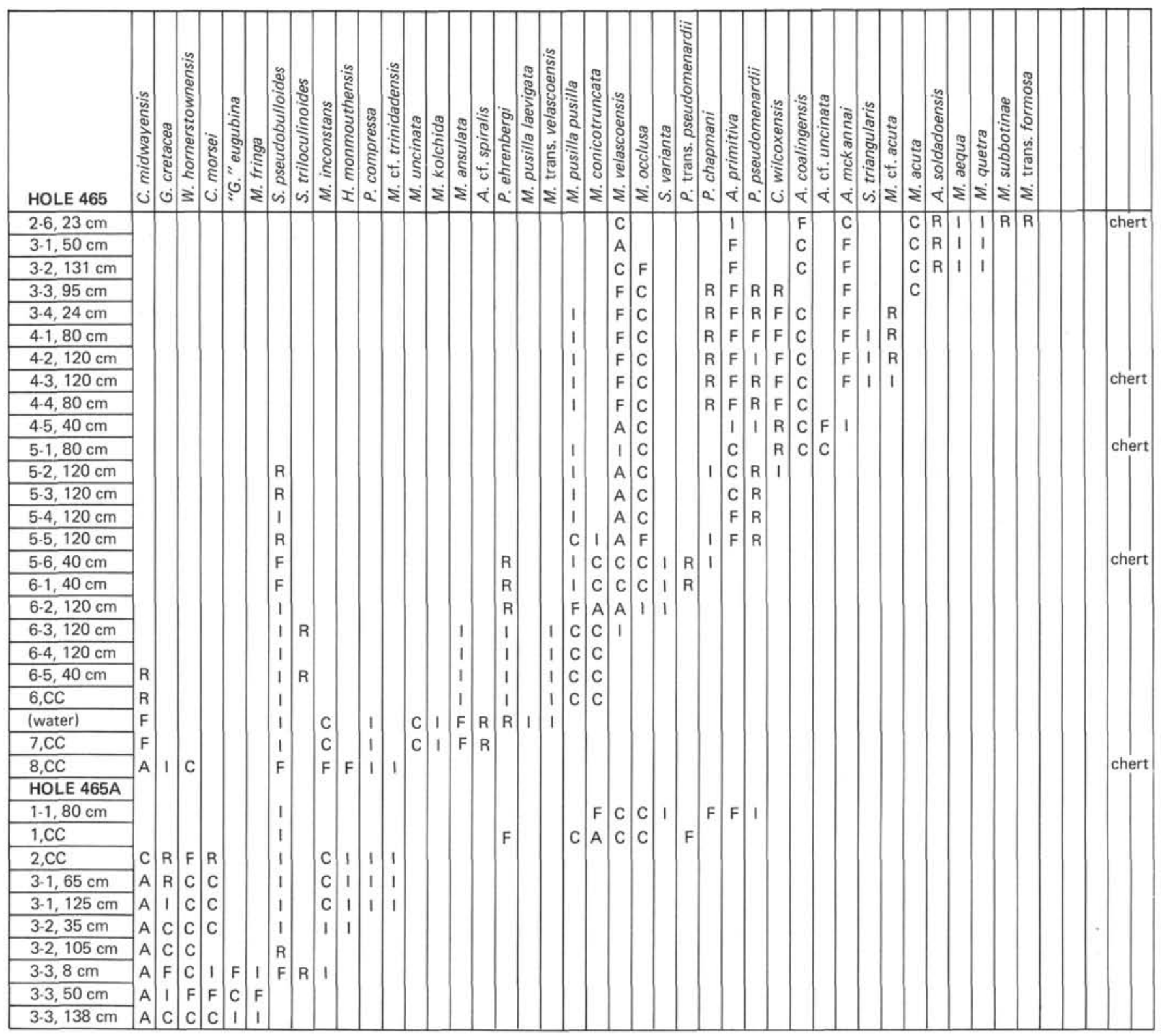

Figure 5. Ranges of selected Paleocene planktonic foraminifers at Site 465. Time scale follows Haräenbol and Berggren (1978). Symbols as in Figure 3.

tundata, and Gtr. stuartiformis are the most common elements in these faunas. At 11-5, there is an interval of recrystallization from which the foraminifers could not be identified.

\section{Site 464}

Site 464 was continuously cored, and Cretaceous sediments were recovered in Cores 11 through 34; however, in all cores only small chips or core-catcher samples were recovered. An interval of red clay extends from the Pliocene to the Cenomanian-Albian.

\section{Preservation}

The preservation was moderate to moderately poor in most samples. Most faunas appeared small, and the fos- sils were tiny, particularly in water samples. Samples commonly contained glauconite, spicules, chert, glass, and feldspar.

\section{Foraminifer Faunas}

Included among abundant siliceous fossils were tiny planktonic foraminifer populations dominated by hedbergellids, globigerinelloids, and Ticinella $\mathrm{cf}$. T. primula. Shackoina cenomana occurred in one sample. In one or more samples, Hedbergella delrioensis, $\mathrm{Hd}$. planispira, and Ticinella sp. aff. T. madecassiana were found. These samples were placed in the Albian, and the higher sample with $S$. cenomana was tentatively placed in the $P$. buxtorfi-R. apenninica Zone, which often contains this fossil. 


\section{Site $\mathbf{4 6 5}$}

This site was continuously cored, and faunas from the late Albian to the latest Maastrichtian were retrieved. The Cretaceous/Tertiary boundary was recovered in Hole 465A, Core 3. Hiatuses in this section occurred in the Cenomanian to Santonian, the Santonian to Campanian, and in the Maastrichtian.

\section{Preservation}

Recrystallization is intense in the Albian (Cores 40-34), above which preservation improves, except that the fossils are squashed. Preservation deteriorates again in Cores 30 to 28, where dissolution and recrystallization are common at most levels. By the Cenomanian $(27, \mathrm{CC}$ to $25, \mathrm{CC})$, sediments are slightly less recrystallized. Above the hiatus to the Santonian, fossils are better preserved, but dissolution is intense in Cores 24 and 25 . The Campanian sediments $(20$ to $12, \mathrm{CC})$ are generally moderately well preserved, except for dissolution intervals connected with chert in Cores 20 to 16 and 12 . Maastrichtian faunas are well preserved, except for an episode of dissolution associated with chert just below the Cretaceous/Tertiary boundary in Core 3 .

\section{Foraminifer Faunas}

Poor preservation dominates the $P$. buxtorfi-R. apenninica Zone $(40-1$ to $27, C C)$. Foraminifers are dolomitized in the lower cores, and diluted by abundant radiolarians in some samples. Both the fossils and the faunas are small in most samples. Hedbergellids are the most common components of the faunas, but small, infrequent specimens of Rotalipora apenninica in Core 40 and a fossil related to Planomalina buxtorfi in 37-1 locate these faunas in the $P$. buxtorfi-R. apenninica Zone. In Core 34-1 there is a major change in the faunas; all fossils become larger, Ticinella spp. increase in abundance, and radiolarians occur only in discrete interlayers. In Core 32 , tiny praebuliminids become a very common component of the faunas. Smaller faunas and individuals return as preservation worsens in Cores 31 and 30 . In Core 28 , there is a notable increase in the rotalid benthics; abundant plant fibers, fish debris, and brown clay occur in 27 , along with some mollusk fragments.

The Rotalipora gandolfi-R. greenhornensis Zone is located in Core 27 by the appearance of $R$. gandolfi. Hedbergellids, rotaliporids, and size-sorted mollusk debris are common in this core. Bad preservation renders the fossils barely recognizable in some sections.

The Gtr. concavata-Gtr. elevata Zone (Cores 25 to 20-2) is recognized on the basis of the overlap of the $D$. concavata group and Gtr. elevata. Globotruncana arca, Gtr. stuartiformis, and Hx. striata all occur in this interval. Some faunas are depleted because of dissolution or sorting, so that only Heterohelix spp., Globigerinelloides spp., and Gtr. elevata are common. The first Nuttalides truempyi accompanies radiolarians, dolomite rhombs, and pyrite among the foraminifers in 21-4.

With the first occurrence in abundance of Gtr. calcarata (20-2), the zone of that name is recognized (20-2 to $12, \mathrm{CC})$. Globotruncana calcarata is accompanied by Gtr. subspinosa. Very high-spired Gtr. calcarata occurs in 18-2. Globotruncana fornicata is less abundant in Cores $21,19,16$, and 15 . The heterohelicids are the most abundant component of most faunas; $R$. rugosa is infrequent in most samples at this site. Globigerinelloides asperus is often common, but the smoother $G$. prairiehillensis is rare or absent at this site. The first rugotruncanids occur in 17-2, but they are not common. The most common globotruncanids are Gtr. tricarinata, Gtr. stuartiformis, and Gtr. fornicata, Gtr. arca being slightly less abundant in most samples. The benthic Aragonia first occurs in 16,CC.

The disappearance of Gtr. calcarata, and the presence of the Gtr. scutilla faunas, including Psg. costulata, characterize the Gtr. scutilla Zone. However, the lack of Gtr. gansseri, and the presence of Psg. excolata in 9-3, suggests that that fauna could belong to the Gtr. gansseri Zone, in which it is tentatively placed here $(12, \mathrm{CC}$ to $8, \mathrm{CC})$. Faunas are dominated by Gtr. stuartiformis and the heterohelicids, although heterohelicids other than Heterohelix are not common at this site. Gublerina first occurs in 11,CC. In 9,CC, Inoceramus prisms and other invertebrate debris are relatively frequent. In 9-3, both Gtr. fornicata and the rugotruncanids increase in abundance, ornamentation becomes more pronounced, and many individuals are higherspired than in previous samples.

The first Globotruncana contusa occurs in 8,CC, thus defining the base of the zone of that name. The Gtr. contusa Zone $(8, C C$ to $3, C C)$ includes the most abundant levels of Globotruncanella havanensis (8-1), as well as one specimen of Gtr. gansseri (6-4). Globotruncana contusa, Gtr. stuarti, R. rotundata, and $R$. fructicosa are typical components of the faunas.

Abathomaphalus mayaroensis occurs abundantly in Core 3, thus defining the Ga. mayaroensis Zone. Faunas are depleted because of intense dissolution, so that benthic faunas are enriched in many levels by the loss of the planktonics; Psg. excolata is the most common planktonic foraminifer. Chert is very common in this interval.

\section{Site 465}

Three cores of the Late Cretaceous $G a$. mayaroensis Zone were retrieved from Hole 465 . Faunas are well preserved and belong to the upper part of the Ga. mayaroensis Zone. Globotruncana cretacea, common in Core $10-1$, was not found in nearby Hole 465A, suggesting better preservation of sediment in 465 (Sliter, 1971). Globigerinelloides asperus, rugotruncanids, and the Gtr. stuarti-stuartiformis groups are the most common constituents in 10-4; Globotruncana contusa is more abundant in 9,CC.

\section{Site 466}

The Cretaceous section recovered at this site includes lower Maastrichtian and upper Campanian to upper $\mathrm{Al}$ bian sediments. Hiatuses span the Cenomanian, and parts of the Turonian, Coniacian, and Maastrichtian. Most of the samples below the lower Maastrichtian to 
upper Campanian are only core-water samples, so the faunas are highly reduced in size, size-sorted, and lack globotruncanids in many instances, making zonal assignation difficult. Preservation of the Upper Cretaceous material is only moderate, and Albian faunas are generally poorly preserved.

Sediments of the $P$. buxtorfi-R. apenninica Zone (Cores 29 to 35 ) contain partially recrystallized planktonic foraminifers. Rotalipora apenninica is present throughout the section, but $P$. buxtorfi was not found. By reference to the $R$. apenninica interval of Luterbacher (1975), this interval is placed in the upper Albian.

The Globotruncana renzi-Gtr. sigali Zone (Cores 28 to 24) lacks most index fossils, but does contain specimens of $M$. renzi, Gtr. fornicata, and Gtr. lapparenti. The lack of $D$. concavata suggests that these faunas then belong to the Gtr. renzi-Gtr. sigali Zone. Within these samples, pyrite, radiolarians, chert, and glauconite are common, while the larger planktonic foraminifers are not. One broken piece of an orbitoidal foraminifer was found in Core 25; this may indicate redeposition from a shelf-depth environment.

The Gtr. concavata-Gtr. elevata Zone was recognized in Cores 21 to 16. Globotruncana fornicata, $D$. concavata, D. assymetrica, G. asperus, and Rugoglobigerina pilula were all found in 21,CC; fine fractions in other samples contain abundant Heterohelix spp., G. asperus, $G$. prairiehillensis, and Clavihedbergella. In $16, \mathrm{CC}$ the radiolarians are beautifully preserved, whereas the planktonic foraminifers are heavily bored. Planoglobulina glabrata was also found in this sample.

Cores 15 to 10 have been ascribed to the upper Campanian Gtr. calcarata Zone, despite the lack of the nominate taxon, because of the abundance of Campanian faunas and $R$. subcircumnodifer, but the lack of typical lower Maastrichtian rugotruncanids as seen at nearby Site 465 . Faunas typically consist of Globotruncana stuartiformis, Gtr. elevata, Gtr. fornicata, Gtr. tricarinata, $R$. rugosa, S. multispina, Psg. costulata, and $R$. subcircumnodifer. Preservation is usually only moderate, and dissolution removal of faunal elements intense. Fragments of benthic foraminifers, chunky carbonate, glauconite, and large rock fragments occur in $14, \mathrm{CC}$; all but the rock fragments occur occasionally in all other samples of this zone. Eocene planktonic foraminifers are found mixed with faunas of Core 10 .

\section{Paleogene}

Paleogene sediments were recovered at Sites 463, 465, and 466. At all sites, part of the section comprises a "'mixed zone,"' with fossils of Oligocene through Campanian age admixed in varying proportions. The thickness and character of the mixed zone varies from site to site.

At Site 463, Cores 5 through 8 contain mixed faunas; levels include pure Cretaceous dissolved faunas, pure Eocene faunas in Cores 7 and 8, and mixed Cretaceous, Eocene, and Oligocene faunas in Cores 7 through 5.

At Site 465 , only a small section of Core 2 contains mixed faunas of Cretaceous, Eocene, and Oligocene age. These faunas are underlain by a continuous Paleocene section. At Site 466, the only Paleogene material occurs in Cores 7 through 10. At the top of the section, Campanian and upper Maastrichtian fossils are mixed with middle Eocene and some upper Eocene and middle Oligocene foraminifers. At the bottom of the section, Eocene and upper Maastrichtian fossils are mixed with phillipsite, glauconite, manganese, and fish debris. Eocene fossils dominate in all samples.

\section{Site $\mathbf{4 6 3}$}

Paleogene sediments occur in Cores 8 to 5-1. The upper Oligocene $G$. ampliapertura Zone and the middle Eocene Globigerinatheka kugleri Zone $(6, \mathrm{CC})$ are present at discrete levels; all other levels contain mixed Cretaceous, Eocene, and Oligocene sediments. The percentage of Oligocene sediments is greater in Cores 5-1 to 6-5; faunas included Chiloguembelina cubensis, Globigerina ampliapertura, Hantkenina alabamensis, Catapsydrax dissimilis, Globoquadrina venezuelana, and Globigerina tripartita. Eocene and Upper Cretaceous fossils are more common in Cores 7 and 8 . Levels of Cretaceous material only are intercalated in levels of Eocene with few Cretaceous fossils in Core 7. Eocene fossils of the Morozovella formosa formosa Zone (8-2), including $M$. formosa, A. quetra, $M$. aragonensis, $C$. wilcoxensis, $A$. primitiva, and $T$. pseudotopilensis, were found in one pure layer.

\section{Site $\mathbf{4 6 5}$}

The Paleocene was continuously cored at Site 465 (Hole 465, Cores 2 to 9; and Hole 465A, Cores 1 to 3-3). The section ranges from late Paleocene Zone P5 to Zone $\mathrm{P} 1$ in 8,CC. Preservation of all samples is good; slight recrystallization is evidenced by microcrystals of calcite on the tests of the morozovellids, particularly on their peripheries.

Fossils of Zone P1 age $(8, \mathrm{CC})$ include Chiloguembelina midwayensis, Planorotalites compressa, Subbotina pseudobulloides, and a rare multi-chambered form resembling Morozovella trinidadensis, but possibly related to Hedbergella monmouthensis. In the Atlantic, this form indicates Zone P1 below the appearance of $M$. trinidadensis.

Zone P2 fossils, determined by the presence of Morozovella uncinata, occurred in 7,CC. Chiloguembelina dominated the faunas, followed in abundance by the morozovellids and Woodringina. Chiloguembelina midwayensis is often large and occasionally spinose, and shows a tendency to develop small terminal chambers and accessory apertures.

Fossils of Zone P3b, the Morozovella pusilla pusilla Zone, occur in Cores 6-5 and 5. Common fossils include Morozovella pusilla, M. conicotruncata, and Acarinina spiralis. Subbotina pseudobulloides is infrequent, and chiloguembelinids are rare. Morozovellids are tightly coiled, with closed umbilici.

Cores 3 to 5-1 are ascribed to the upper Paleocene Planorotalites pseudomenardii Zone. Chiloguembelina is infrequent, as morozovellids dominate the faunas. Morozovella velascoensis, Acarinina coalingensis, Plan- 
orotalites pseudomenardii, Acarinina primitiva, and $M$. pusilla are all present. Eocene fossils of Zone P6 occur at the top of Core 3 and at the base of Core 2, where they are mixed with middle Eocene and Pliocene fossils.

The Cretaceous/Tertiary boundary is contained in Core 3-3 of Hole 465A (Fig. 6). Cretaceous sediments at the bottom of the section are stark white, with occasional splotches of black material identified as pyrite. Chert fragments are common in this sediment, which is chalky and contains dissolved foraminifer faunas. At $140 \mathrm{~cm}$, white Cretaceous material is streaked through the center of a grayish sediment of Paleocene age. The contact between the streak of Cretaceous and the Paleocene is sharp, so that is possible to sample pure faunas of either age at this level. Above $110 \mathrm{~cm}$, no further white sediment is seen, and the black pyrite splotches do not occur.

Because of dissolution of the Cretaceous sediment, it is not possible to determine if the uppermost Cretaceous is present. The basal "Globigerina" eugubina Zone is present at $138 \mathrm{~cm}$; it is very well preserved and contains faunas similar to the "G." eugubina Zone at other DSDP sites, except for the greater abundance of Chiloguembelina and Guembelitria at some levels. Hedbergella monmouthensis, which occurs in the "Globigerina" eugubina Zone faunas of Atlantic Sites 356 and 384 , and in cores from Agulhas Plateau, is present also at this site.

Zone $\mathrm{P} 1 \mathrm{a}$ is present above the G. eugubina Zone in Core 3; faunas include Chiloguembelina morsei, Subbotina pseudobulloides, Hedbergella monmouthensis, Morozovella inconstans, and G. cretacea. Upper Zone $\mathrm{P} 1$ is found in Core 3-1 through Core 2. Chiloguembelina midwayensis is abundant, accompanied by $S$. pseudobulloides, $M$. inconstans, $H$. monmouthensis, $H$. sp. cf. H. monmouthensis (resembling $M$. trinidadensis), and striate chiloguembelinids. Core $1, \mathrm{CC}$ contains fossils of the Zone P3b. The dominant element of the faunas has changed from Chiloguembelina spp. to Morozovella pusilla. Morozovella velascoensis and Planorotalites chapmani are also common; acarininids and subbotinids are less common in these faunas.

\section{Site 466}

Cores 7 through 10 contain mixed assemblages of Cretaceous, Eocene, and Oligocene planktonic foraminifers. Oligocene fossils dominate in Core 7 , whereas Eocene faunas predominate in Cores 8 to 10. Preservation is selective: fragile Oligocene species are not found in the upper core, whereas the robust morozovellids and acarininids predominate in lower faunas. Some of the in-mixed Cretaceous fossils are better preserved in these levels than in the in situ Cretaceous below. In some Eocene levels, middle Eocene fossils are recrystallized, whereas lower Eocene specimens are not.

Included in Core 7 are Globoquadrina venezuelana, Turborotalia opima, Chiloguembelina cubensis, Gtr. elevata, Gtr. fornicata, and $R$. fructicosa. The core catcher of 7 contains more Cretaceous than Eocene or Oligocene fossils. By contrast, 10,CC is largely composed of Eocene fossils, with little in-mixed Cretaceous.
Fossils include $M$. aragonensis, $A$. soldadoensis, $G$. kugleri, Gtr. contusa, Psg. excolata, and Gtr. calcarata. The presence of Gtr. calcarata in Core 10,CC is important, because this fossil is not found in sediment of that age in the in situ Cretaceous below.

\section{COMPARISON WITH OTHER CENTRAL PACIFIC DSDP SITES}

Cretaceous and Paleogene sediments have been recovered at 13 other central Pacific DSDP sites (Luterbacher, 1975; Caron, 1975; Toumarkine, 1975; Fleischer, 1975; McNulty, 1976; Douglas, 1971, 1973; Krashenninikov, 1971, 1973) (Table 1). The biostratigraphy of these sites is briefly recapitulated below to allow comparison with sections of Leg 62 . Zonal names from these reports are retained.

\section{Cretaceous}

\section{Site 305}

Upper Cretaceous sediments are well preserved, except those from the A. mayaroensis Zone, which are very dissolved. Beginning in the upper Campanian, dissolution becomes intense again and continues so down to the Aptian. Black shales are reported in the Aptian here, as well as at Site 306.

\section{Site $\mathbf{3 1 0}$}

The only Maastrichtian fossils are redeposited, overlying a good interval belonging to the Gtr. concavata Zone, the Coniacian, the $P$. helvetica Zone, and the $R$. apenninica Zone of the Cenomanian. Black shales in the Cenomanian are reported at this site from only one fragment in a core catcher.

\section{Site 313}

This site contains well-preserved lower to middle Maastrichtian sediments, below which preservation declines rapidly through the upper and lower Campanian.

\section{Site 51}

Only the Gtr. concavata Zone and Ticinella from the Albian are recorded here.

\section{Site 47}

The A. mayaroensis Zone is inferred from the nannofossil $M$. mura Zone. Underlying this zone, there is a nannofossil chalk and ooze with Inoceramus, belonging to the Gtr. gansseri Zone.

\section{Site 169}

This site contains upper Cenomanian pink to white chalks.

\section{Site 170}

This site lacks the upper Maastrichtian, but begins in the lower Maastrichtian R. subcircumnodifer Zone. Below are ashy, cherty, zeolitic mudstones, which contain identifiable fossils of the $R$. evoluta Zone. 


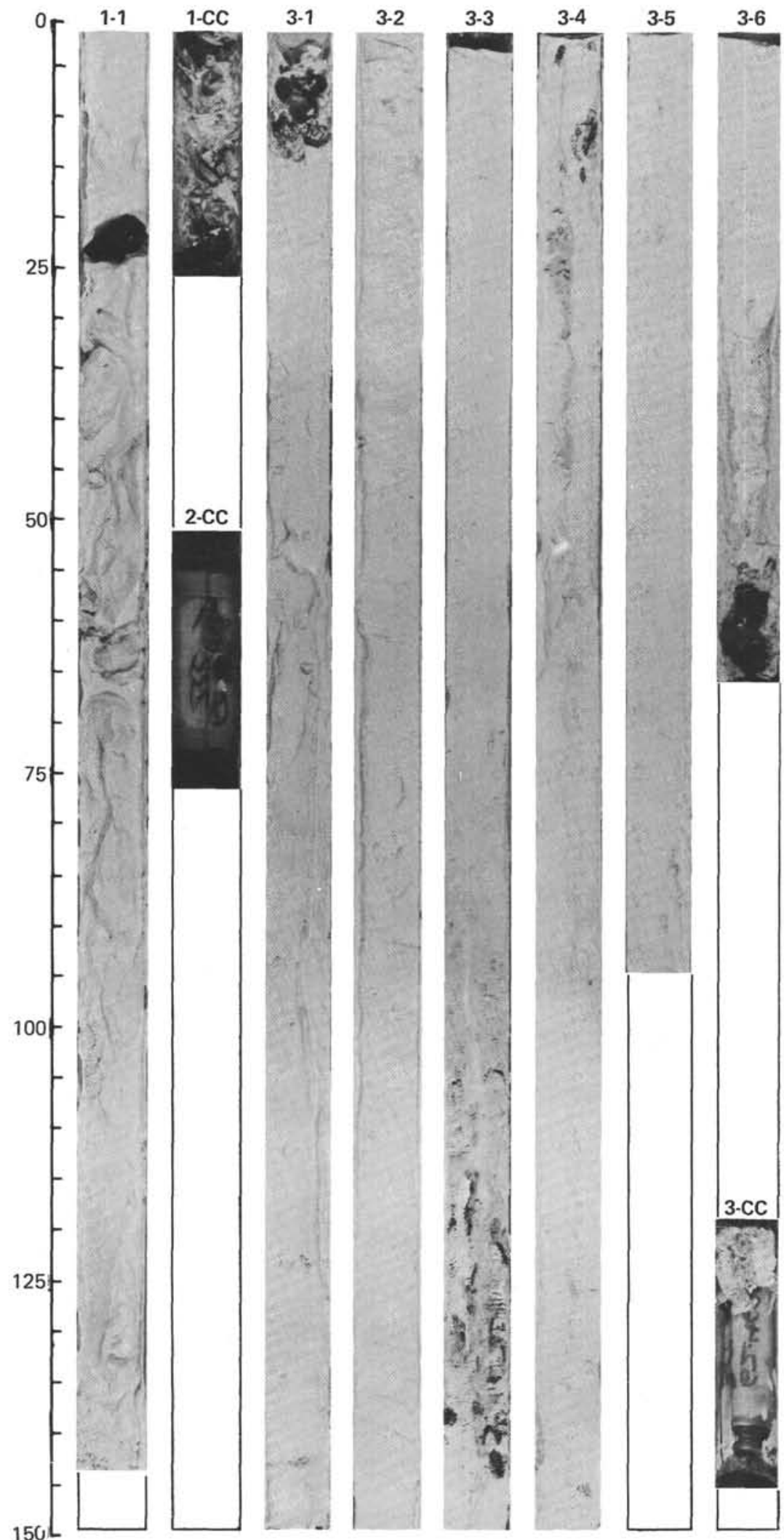

Figure 6. Photograph of Cores 1, 2, and 3 from Hole 465A. The Cretaceous/Tertiary boundary occurs at 3-3, $138-140 \mathrm{~cm}$. The white stringer at the base of this section is the Cretaceous material which has been spread into the Paleocene section during the drilling process. Black splotches are pyrite. The disturbed Late Cretaceous zone of chert and dissolved carbonate can be seen from Section 4 to the core catcher. 


\section{Site 171}

This site contains a complete section of Maastrichtian and upper Campanian, underlain by a hiatus from the Gtr. calcarata to Gtr. concavata Zones. The M. renzi and $P$. helvetica Zones overlie a volcanic siltstone of Cenomanian age.

\section{Site 167}

This site includes a complete Maastrichtian and Campanian section. Santonian fossils below are dissolved, so that only the nannofossil zones can be recognized. The Santonian-Coniacian contains primarily neritic benthics. The Aptian at this site is brownish-yellow cherty limestone.

\section{Site 199}

This site contains badly dissolved $A$. mayaroensis Zone fossils.

\section{Site $\mathbf{2 8 8}$}

There is a 30-meter coring gap between the Danian and the Gtr. gansseri Zone, so that the $A$. mayaroensis Zone may have been present, but uncored. The lower Maastrichtian is present, but between the $M$. subcircumnodifer Zone and the Cenomanian the foraminifers are dissolved, and there are few nannofossils. Improved preservation allows recognition of the Cenomanian $R$. greenhornensis Zone; the section bottoms in the Albian/Aptian.

\section{Site 289}

There is a 20-meter coring gap between the Danian and the Gtr. gansseri Zone at this site. However, the nannofossil $M$. mura Zone is present, suggesting that the $A$. mayaroensis Zone was deposited, but the zonal marker removed. The lower Maastrichtian and upper Campanian are represented, but from the lower Campanian to the Aptian there is a hiatus. Aptian sediments are pinkish-gray, siliceous limestones.

\section{Site 45}

This site contains a greenish-gray Cenomanian level.

\section{Paleogene}

\section{Site 305}

This site produced heavily dissolved Oligocene sediments, a dissolved and impoverished middle Eocene fauna, and a well-preserved Paleocene section. The lower middle Eocene is considered missing, and there is a hiatus across the Cretaceous/Tertiary boundary. The M. subbotinae Zone is missing, but all other Eocene to upper Paleocene zones are present; the Danian was not reported. Morozovella formosa is heavily ornamented, tending to $M$. crater.

\section{Site 310}

Dissolution was so strong that the Oligocene to Maastrichtian section could not be zoned. Only the $G$. ampliapertura Zone was recognized. Sedimentation rates were reportedly low in the middle Eocene and the Oligocene; there is a hiatus in the upper Oligocene.

\section{Site 313}

The Oligocene contains only the G. opima and $G$. ciperoensis Zones; there is a dissolution hiatus between the lower Oligocene and the middle Eocene; the $M$. subbotinae Zone is present, but most of the Eocene is heavily contaminated with Paleogene reworking. Most of the Paleocene is missing, as on the Magellan Rise and Horizon Guyot.

\section{Site 44}

The section is nearly continuous from the middle Eocene through the lower Oligocene; all zones except P15 are identified, but sedimentation rates were very low.

\section{Site 167}

The upper Oligocene is missing; however, all zones of the lower Oligocene through the middle Eocene Zone P13 are represented. Chert and a hiatus occupy what would be the middle Eocene, followed by a hiatus spanning the upper Paleocene.

\section{Site 171}

There is a hiatus between the lower Oligocene and the middle Eocene Zone P14; Zone P13 is found, followed by a second gap to the Cretaceous.

\section{Site 199}

This site contains the Paleocene, but not the Danian.

\section{Site 200}

Only the $M$. formosa Zone can be recognized; morozovellids and acarininids display a surprising abundance of secondary sutural apertures; high accumulation rates are reported in the upper Paleocene and lower Eocene.

\section{Site 202}

This site contains poorly preserved fossils from the O. beckmani Zone.

\section{Site 288}

The Oligocene (Zones P22 and P19) are well represented, followed by a coring gap and hiatus to the upper Paleocene; the Paleocene section extends to the Danian.

\section{Site 289}

A long Oligocene, including Zones P22, an extended $\mathrm{P} 21$, and a part of P19, is followed by a hiatus to the upper Eocene P16. Upper Eocene Zone P15 and middle Eocene Zone P14 are present above the chert, which makes zonation below indefinite. Zone P11 was identified overlying fossils of Zone P8; the section continues from Zone P7 to P3, only Zone P6 being absent.

\section{Site 47}

This site contains a hiatus from the upper Miocene nannofossil $C$. tricorniculatus Zone to the middle Eo- 
cene $G$. bullbroki Zone (P11). The section below Zone P8 contains all Eocene and Paleocene zones, including the " $G$." eugubina Zone.

\section{Site 45}

This site contains only an upper Eocene ash deposit, containing the nannofossil $D$. barbadiensis, and a part of the Oligocene in one core.

\section{Hiatuses}

There are multiple reported hiatuses in the various Pacific Paleogene and Cretaceous sites discussed above. Lancelot and Larson (1975) report that the Paleocene-lower Eocene hiatus is widespread in the Pacific, although they speculate that it may be unique to plateau regions in the highly productive equatorial zone. They also suggest that hiatuses are longer in the deeper middle-latitude sites. The previous summary of the hiatuses reported in the Paleogene and Cretaceous suggests that the times of extensive loss of material (or non-deposition) are the late Eocene, the early Eocene to late Paleocene, the Cretaceous/Tertiary boundary (including part of the $G a$. mayaroensis Zone), and part of the Campanian to Santonian. The generally poor preservation of most Cretaceous sediments older than the Campanian makes it difficult to assess actual hiatuses in these sections.

Significant exceptions are the middle Eocene to lower Oligocene section at Site 44, the complete lower Eocene through Paleocene section at Site 47 , the complete Paleocene section at Site 465, the Paleocene section at Site 47, and the upper Eocene section at Site 289.

The Cretaceous/Tertiary boundary is marked by a disturbed zone in the most complete sections, Site 47 and 465. It is absent at other central Pacific sites.

The most widespread Cretaceous hiatus spans large parts of the $G a$. mayaroensis Zone at seven sites. Parts of the lower Campanian are missing at three sites. That the hiatuses supposed to develop as sites cross the equatorial zone (Lancelot and Larson, 1975) should not necessarily be synchronous between sites may explain the scattered distribution of hiatuses through Cretaceous sections.

\section{SEDIMENTATION RATES}

Sedimentation rates for the four Leg 62 sites in the Cretaceous are plotted in Figure 7. Particularly high rates common among Sites 463,465 , and 466 occur in the Maastrichtian Gtr. contusa Zone and the Gtr. calcarata Zone of the late Campanian. Low rates at all the sites are typical through the Coniacian and early Cenomanian.

At Site 463 , high rates through the Maastrichtian probably occurred as the site entered the equatorial high-productivity zone; however, radiolarians are not abundant through these levels. Stratigraphic uncertainties concerning the presence or absence of the Gtr. stuarti Zone may add to the inflated rates in general. The low value in the Gtr. gansseri Zone should be accurate, as this taxon is a tropical index species and should occur through its full range at Site 463. Low rates in the Turonian, Coniacian, Cenomanian, and Santonian may partially result from transformation of sediment into chert, as well as from erosion. The low rate in the $P$. buxtorfi-R. apenninica Zone is surprising in view of high late Albian rates at many other Pacific and Atlantic DSDP sites.

The sections at Sites 465 and 466 are very similar except that sediment removal, presumed to be caused by the equatorial crossing in the Turonian, ceased earlier at Site 466. High rates in the late Campanian to early Maastrichtian and late Albian are apparently oceanwide phenomena at intermediate-depth sites in middle to low latitudes. The low rates in the Cenomanian are probably the partial result of erosional truncation of parts of those sections at both sites, as well as of chertification of some sediment. The low Cenomanian rate at Site 465 is surprising, as this site is supposed to have received clastic influx at this time. Rates of pelagic sedimentation must have been very low (or erosion of material very active) to produce such low rates even in a turbidite sequence in the high-productivity zone.

\section{REDEPOSITED SEDIMENTS}

Redeposited Paleogene sediments from the so-called "mixed zone" are common at Sites 463,465 and 465 . The differing composition of the nannofloras and planktonic-foraminifer faunas from the same sample suggest not only differential erosion and redeposition of sediments from nearby areas, but also derivation from several different sources.

Redeposited sediments at Site 465 occur primarily in the early Cenomanian and late Albian. Along with the small-sized planktonic foraminifers and neritic benthics were abundant detrital minerals, plant debris, and sizesorted mollusk fragments. The benthic foraminifers and small rotaliporids in these samples suggest a neritic depth of deposition; the mineral and plant debris suggest a shallow shelf to subaerial source for the redeposited sediments.

At Site 466, two modes of redeposition prevailed in the Cretaceous and Paleogene. The Paleogene "mixed zone" at this site contains redeposited Cretaceous and Paleogene planktonic foraminifers, as well as detrital and authigenic minerals, redeposited benthic foraminifers, fish debris, and glauconite. These sediments represent a high-productivity dissolution interval, as well as episodes of normal sedimentation, mixed together. Late Cretaceous samples contain rock fragments, volcanic glass, bryozoans, redeposited benthic foraminifers, and some reworked Eocene fossils. This regime suggests erosion of Eocene sediments from a volcanic source and shallow-shelf environment into normal pelagic accumulations.

Older Cretaceous samples at this site were mainly derived from core water and contained only the fine fractions of the mineral and foraminifer components, along with prisms of Inoceramus. In Core 25, one fragment of a large orbitiodal benthic foraminifer typical of reefs was found mixed with pelagic sediments of Cretaceous age; a few reworked Eocene planktonic foraminifers were also present. The contents of this sample sug- 

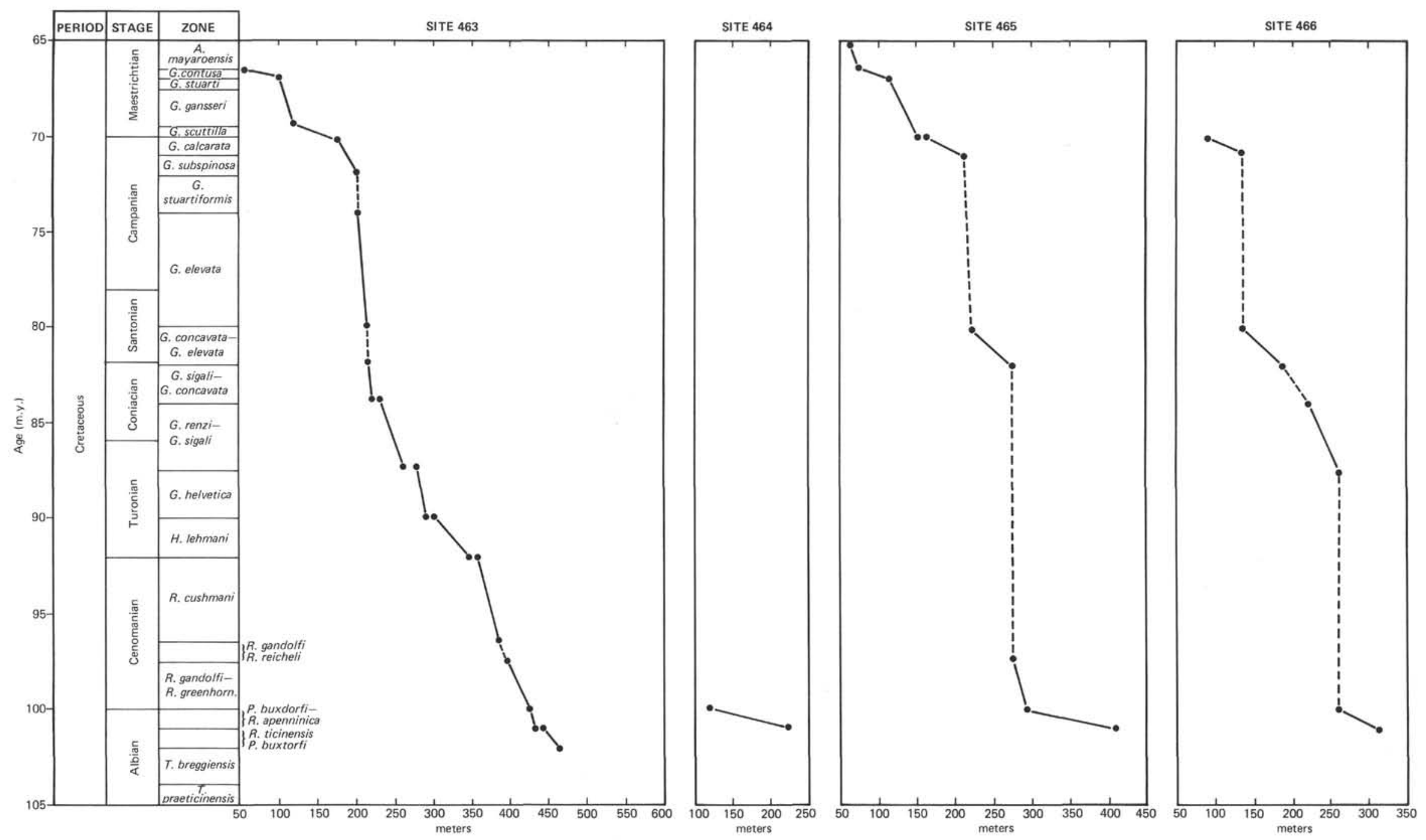

Figure 7. Sedimentation rates in meters per million years at Sites $463,464,465$, and 466 . Horizontal scale is meters in sub-bottom depth at the sites. Vertical scale follows the time-scale of van Hinte (1976). Dotted lines indicated hiatuses in the section. Separate dots at the same levels indicate some interventing sedimentation of indeterminate age. 
gest that the core-water samples were misleading, and that the sedimentation regime of the late Campanian sediments may have occurred back through the Coniacian and Santonian.

Cenomanian sediments at Site 466 roughly resemble those at Site 465 , except that the siliceous and phosphatic contents are higher at Site 466. Radiolarians, chert, fish debris, and normal pelagic sediment at this site are found with detrital minerals, plant debris, and some volcanic glass suggesting distal turbidite deposition, similar to that at nearby Site 465 .

The two major periods of redeposition, the Paleogene and late Albian to Cenomanian, differ not only in the types of sediments, but also in probable cause. Turbidite processes, possibly related to the lower sea levels in the early Cenomanian, were responsible for the redeposited materials at Sites 465 and 466. Erosion of a volcanic and shallow-water sediments produced the sediment pattern at Site 466 during the later Cretaceous. Extreme erosion of pelagic carbonate sediments and redeposition from several sources is the suggested mechanism producing the "mixed zone" faunas of the Paleogene in the central Pacific.

\section{SUMMARY OF SEDIMENTATION HISTORY AT MID-PACIFIC MOUNTAINS SITES}

The Mid-Pacific Mountains Sites 171, 313, 44, and 463 (Table 1; Fig. 8) all contain substantial hiatuses in the Paleogene. The so-called "mixed zone" is present at all the deeper sites, but not mentioned at Site 44, which apparently contains short, sporadic hiatuses in the Oligocene to middle Eocene, which was not continuously cored. The mixed zone is thickest at Site 463 (Cores 4 to 7-3) and 171 (Cores 5 to 9), but very thin at the deepest Site 313 (Core 2), where dissolution effects are common (Toumarkine, 1975).

The Eocene/Oligocene boundary is identified at Site 44, but faunas are highly dissolved (Blow, 1971). At all other sites, this interval has been removed. Roughly similar Eocene levels are preserved intact at these sites, although mixing is intense at Site 463 . Middle Eocene Zones P13 and P14 are best preserved; radiolarians occur commonly in the early and middle Eocene at Sites 171 and 313 , but are not found at Site 463 . Whereas some early Eocene faunas are found at Sites 463 and 313 , most of the early Eocene and Paleocene is missing from the Mid-Pacific Mountains holes.

Only Sites 463, 171, and 313 recovered Cretaceous sections, all of which have short hiatuses in the uppermost Maastrichtian. At that time all of these sites are presumed to have crossed the equatorial zone (Lancelot and Larson, 1975). The middle Maastrichtian to upper Campanian sequence is continuous and well preserved; hiatuses below the Gtr. calcarata Zone occur at Sites 171 and 463 , whereas preservation only deteriorates at Site 313 ; subsequently, this sequence was interrupted by an episode of volcanism and turbidite deposition masking whether the erosional event at Sites 463 and 171 also occurred here. Site 313 bottoms in lower Campanian, overlying basalt.
Sites 171 and 463 contain hiatuses below the upper Campanian Gtr. calacrata Zone; more material is removed from the section at the more-easterly Site 171, which contains a telescoped Santonian to Coniacian section. At Site 463, smaller, discrete portions of the lower Campanian and upper Coniacian are missing. The lower Coniacian and upper Turonian are represented at both sites; however, the section at Site 463 is relatively complete from the Turonian to the Aptian, whereas sediments of this age at Site 171 are poorly preserved and dominated by volcanic input and shallow water fossils.

\section{SUMMARY OF SEDIMENTATION HISTORY AT HESS RISE SITES}

Four Sites, 464, 465, 466, and 310 (Table 1, Fig. 7), have been drilled on Hess Rise. The deepest site (464) contains a $90-m . y$. hiatus, so that only Albian to Aptian sediments were recovered. Site 310 , drilled near 3500 meters, contains a more complete section riddled with intense dissolution intervals and numerous Paleogene and Cretaceous hiatuses.

All Paleogene material is absent from Site 464. Dissolution is very intense at Site 310 , whereas hiatuses and redeposition of material resulting in "mixed zone" faunas are typical at Sites 465 and 466 . Deviations from this regime include a complete Paleocene section recovered at Site 465, and coherent lower Eocene at Site 310. Paleogene radiolarians and zeolites are common in the sediments of the deeper Site 310 , more affected by dissolution, whereas foraminifers and no radiolarians were found at the shallower sites.

The Cretaceous sections are different at each site, and comparison of the section is difficult, because the intense dissolution of faunas at Site 310 has removed many standard index species and required a more local zonation to be used (Caron, 1975). Site 465 contains a complete Maastrichtian sequence; no in situ Maastrichtian is reported from either Site 466 or 310 . The upper Campanian Gtr. calacrata Zone is found at Sites 465 and 466 , but Gtr. calcarata was not identified at Site 310-only Gtr. subspinosa, which does represent the upper Campanian. A thick lower Campanian section is found at Site 310, but not at the other sites, which contain the late Santonian Gtr. concavata-Gtr. elevata Zone, only part of which spans the Santonian/Campanian boundary; it may in part be equivalent to the lowermost part of the section at Site 310 . Site 466 contains lower Coniacian, possibly equivalent to the Coniacian Gtr. primitiva Zone at Site 310; but this entire interval is lacking at Site 465 . At both Sites 465 and 466, the Turonian and most of the Cenomanian are spanned by a hiatus, presumably representing the crossing of the equatorial region. The mid-Turonian Gtr. helvetica Zone, however, is preserved at Site 310 , which should have been in the northern subtropical belt at that time. The lower Cenomanian to upper Albian P. buxtorfi-R. apenninica interval is present at Site 465 and 466; this interval identified at Site 310 may be slightly younger in the Cenomanian, as indicated by the various types of praeglobotruncanids. Site 465 bottoms on volcanic 


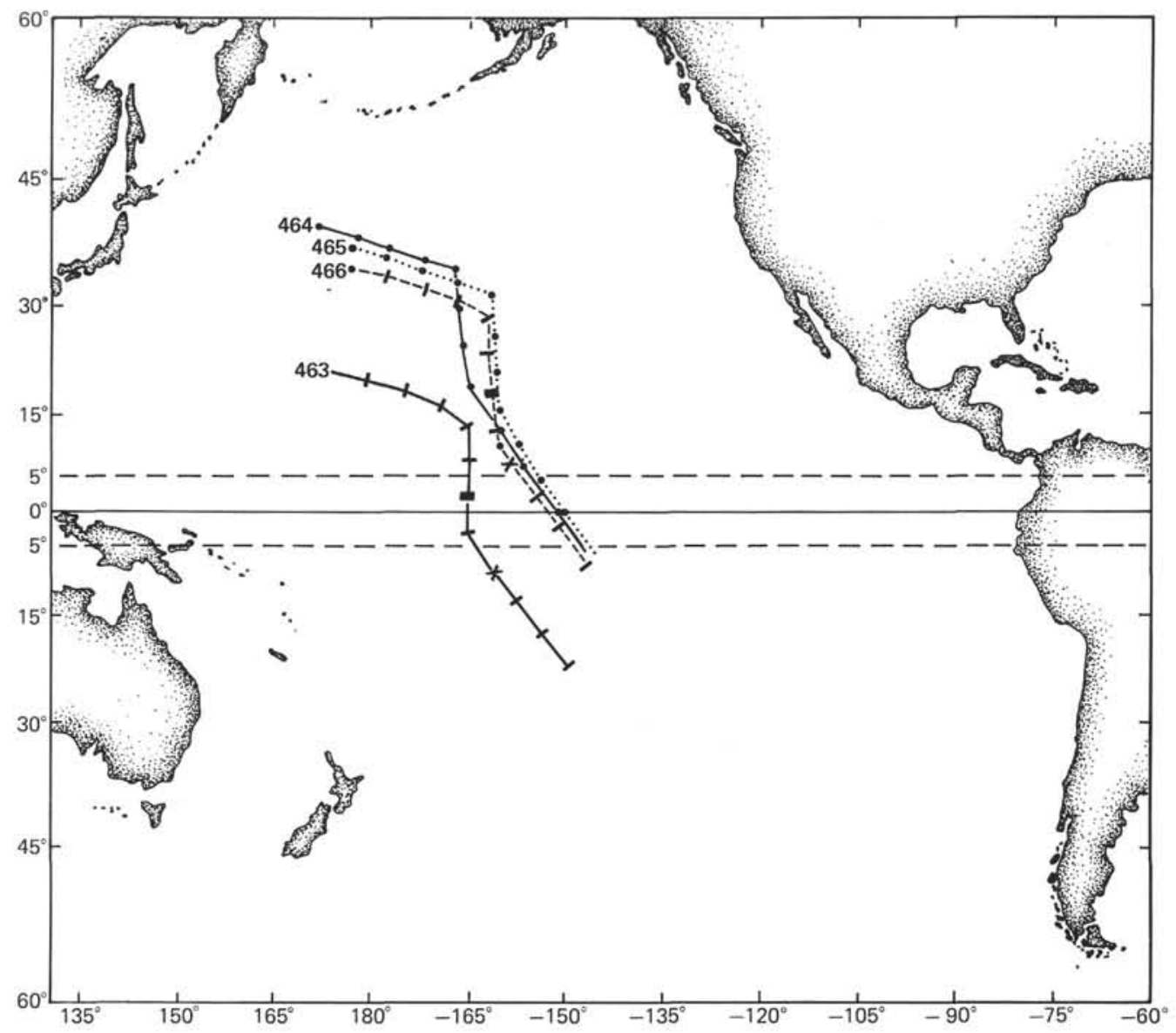

Figure 8. Paleolatitudinal reconstructions of the geographic location of Leg 62 sites in the central Pacific according to the rotational reconstruction model of Lancelot and Larson (1975). Bars along the site path indicate increments of $10 \mathrm{~m} . \mathrm{y}$. The heavy bars indicate the position of each site at $60 \mathrm{~m} . \mathrm{y}$. ago, and the cross the position at $80 \mathrm{~m} . \mathrm{y}$. ago.

rock, overlain by Albian fossils and shallow-water detrital fossils and redeposited clastic sediment of a hemipelagic nature. The amount of redeposited shallowerwater materials and sediment is less at Site 466.

Foraminifers of Albian age are preserved at Site 464, which presumably lay above the CCD in the equatorial zone between 100 and 110 m.y. ago. Siliceous fossils, benthic invertebrate fossils, and some redeposited benthic foraminifers are present, and sedimentation rates are very high.

\section{CRETACEOUS PLANKTONIC FORAMINIFER PALEOECOLOGY}

Leg 62 Cretaceous faunas all lived in the Tethyan belt (Sliter, 1972) of the Pacific. Faunas at Site 465 are most similar to those reported from the latitudinally equivalent Shatsky Rise (Douglas, 1971; Caron, 1978), and dissimilar to the other Hess Rise site (310), which was at a slightly higher latitude. Site 463 faunas resemble southern Tethyan faunas, but lack Gtr. falsostuarti and abundant Globigerinelloides (Caron, 1978; Olsson, 1964; Pessagno, 1960, 1962; Said and Kenawy, 1956; Bolli, 1957). Comparison of faunas between Sites 463 and 465 is shown in Figures 3, 4, and 9. The frequent episodes of dissolution make comparison of faunas dif- ficult, so that the relative frequencies of each taxon throughout the stage or zone are compared. The absence of Gtr. havanensis at many levels at both sites suggests that some dissolution has occurred. The presence of Gtr. cretacea at 465, but not at coeval levels at 465, indicates removal of species from 465 faunas. Concentration of the resistant species Gtr. arca and Gtr. stuartiformis (Sliter, 1972) at Site 465, in the CampanianMaastrichtian, then, may be the result of dissolution of other taxa. By contrast, concentration of the dissolution-susceptible species Gtr. ventricosa (Sliter, 1972) at 463 suggests better preservation at this site. There are, however, levels at Site 465 (8,CC and 8-2) where dissolution becomes more pronounced and Gtr. havanensis is enriched, indicating that more study of dissolution of Cretaceous planktonics is warranted.

While coeval faunas at Sites 463 and 465 share nearly all species in common (Gtr. gansseri is the exception), relative abundances and morphotypic expression differ between the two sites. Species such as Gtr. stuarti, Gtr. ventricosa, $R$. subpennyi, and some Globigerinelloides spp. are larger at Site 463 and apparently higher-spired. Rugotruncanids and rugoglobigerinids are much more abundant at Site 463, as are the rotaliporids in the Cenomanian. The endemic Tethyan forms $A$. intermedius, 

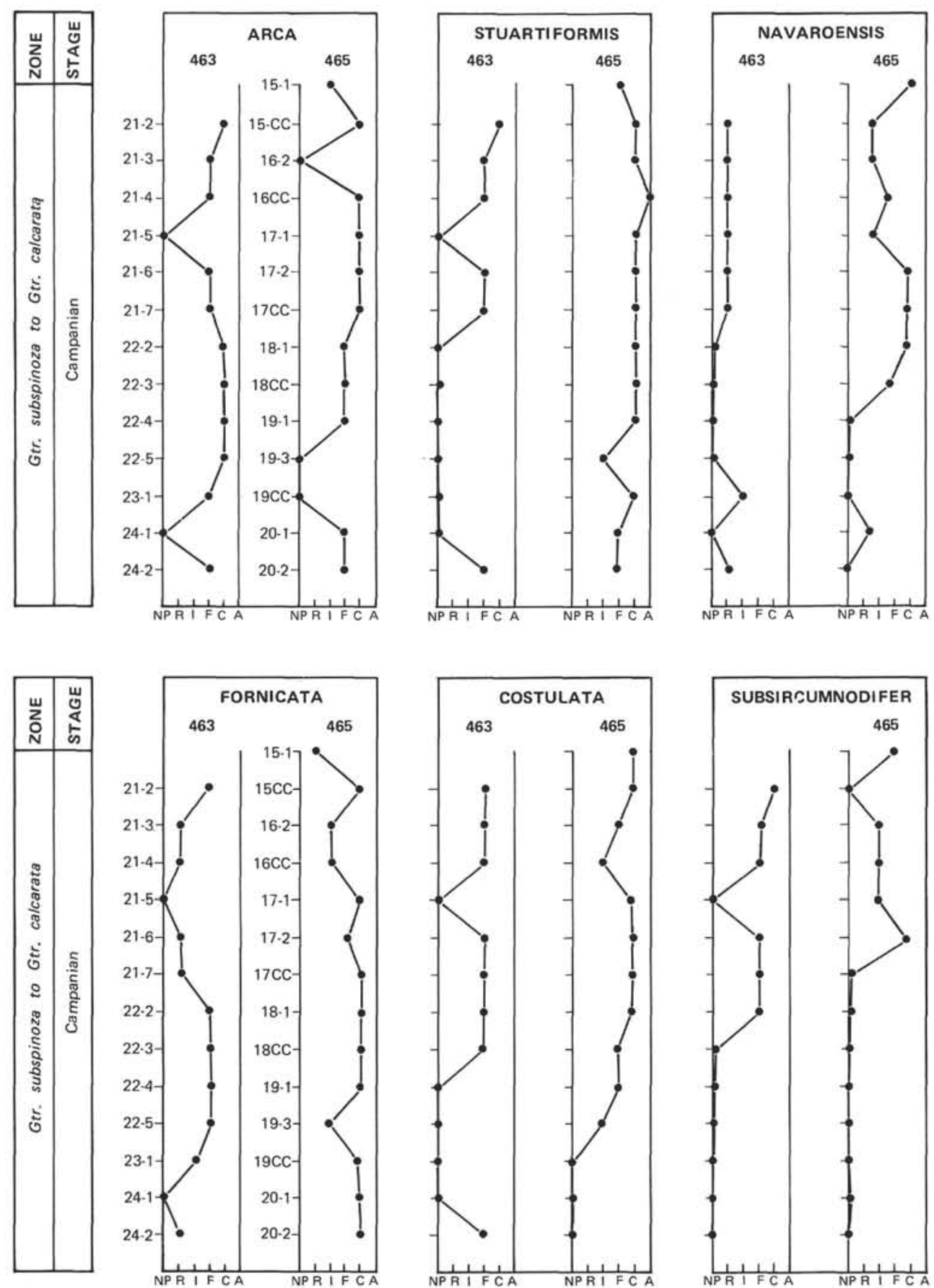

Figure 9. Relative frequencies of six Cretaceous planktonic-foraminifer species at Sites 465 and 463 during the late Campanian. Data are taken from Figures 3 and 4. Symbols include: NP, not present; R, rare; I, infrequent; $\mathrm{F}$, frequent; $\mathrm{C}$, common; and $\mathrm{A}$, abundant. The charts demonstrate the greater overall abundance of these species at most levels at Site 465 .

Gtr. gansseri, Gtr. stuarti, and R. subcircumnodifer overall abundance at Site 463 , whereas Gtr. contusa, (Sliter, 1972) appear more consistently and in greater also a Tethyan endemic in Sliter's 1972 scheme, is more common at Site 465. During deposition of the Gtr. contusa Zone, Site 465 should have been located near $15^{\circ} \mathrm{N}$, while Site 463 lay at the equator; their positions suggest that Gtr. contusa is indicative of the central Pacific sub- tropical belt, rather than the equatorial fauna. Globotruncana arca, which can penetrate into the boreal zones (Sliter, 1971), was more abundant at Site 463, along with the endemic Tethyan faunas.

\section{Equatorial and Subtropical Faunas}

According to the rotational reconstruction model of Lancelot and Larson (1975) the times of equatorial 
crossing for Sites 463 and 465 are estimated at 65 to 70 and 95 to 90 m.y. ago, respectively (Fig. 8). Faunas deposited at this time could constitute the equatorialwater-mass faunas, distinct from those of the subtropics. From 70 to 80 m.y. ago, Site 465 lay just within the northern subtropical belt, while Site 463 was situated in the southern subtropics; faunas might be expected to show a high degree of correspondence.

Site 465 was situated at the equator at approximately 90 m.y. ago; there is a hiatus at this site corresponding to that time. Just before arriving at the equator, Site 465 accumulated sediments of early Cenomanian age, which are poorly preserved. These sediments were probably deposited in slope-depth water, and are accompanied by clastic sediments, redeposited, size-sorted mollusk fragments, and plant fiber. Radiolarians, common in older samples, are absent in the Cenomanian, although small stringers of chert do punctuate the limestones. The planktonic foraminifers are small; common elements include Rotalipora apenninica, $R$. gandolfi, $H d$. delrioensis, Hd. amabilis, Hd. planispira, and G. caseyi. Although deposited close to the equator, these faunas are strongly affected by the local depositional environment and cannot be used to describe the equatorial fauna of the Cenomanian.

Reconstructions place Site 463 at the equator 65 to 70 m.y. ago. As at Site 465, the equatorial crossing is marked by a hiatus. Maastrichtian faunas often bear evidence of dissolution and etching; chert is infrequent to frequent in some samples, but no radiolarians were found. Sedimentation rates for the early Maastrichtian are high, however. Planktonic-foraminifer faunas commonly contain Gtr. stuartiformis, Gtr. arca, R. subcircumnodifer, other rugotruncanids, R. rugosa, Psg. costulata, and Psg. excolata. In low abundance we find Gtr. fornicata, Gtr. elevata, Gtr. gansseri, and P. elegans. Planoglobulina glabrata is generally rare. Highspired morphotypes of Gtr. gansseri, Gtr. ventricosa, and $R$. subpennyi typify these faunas. Particularly large individuals of Gtr. ventricosa, R. subpennyi, Globigerinelloides spp., $H$. navarroensis, and later, Gtr. stuarti are common. Heterohelix navarroensis variants are pronouncedly nodose, whereas at some levels $P$. elegans has spinose striae. The ridges on Psg. excolata are particularly wide and platy at this site. Spinose ornament is highly developed on $R$. scotti and $R$. rugosa.

Northern and southern subtropical faunas of late Campanian age differ between the two sites. Site 463 ( 5 to $10^{\circ} \mathrm{S}$ ) contain the same species as Site 465 (5 to $10^{\circ} \mathrm{N}$ ); only the relative proportions of taxa differ, as does the state of preservation of the sediments at some levels.

At Site 463, common species include Gtr. arca, Gtr. elevata, Gtr. subspinosa, Gtr. calcarata, Gtr. tricari$n a t a$, and (at the top of the section) the rugotruncanids. Less frequent are Gtr. fornicata, R. rugosa, Gtr. stuartiformis, and Psg. costulata. Globigerinelloides spp., $P$. glabrata, $H$. navarroensis, $P$. elegans, and $A$. intermedia are generally rare.

By contrast, Gtr. arca, Gtr. elevata, Gtr. subspinosa, Gtr. calcarata, and the rugotruncanids are relatively un- common at Site 465. More-common species include Gtr. fornicata, Globigerinelloides spp., Gtr. stuartiformis, Psg. costulata, and $H$. navarroensis; Abathomphalus intermedia and $P$. glabarata are generally rare. Differences between the two sites are even more pronounced in the Maastrichtian.

Dissolution has in part selectively altered faunas at the two sites; however, many dissolution-susceptible taxa persist in Campanian faunas. Futhermore, the process has concentrated different species (both solution-resistant and solution-susceptible) at the two sites. Thus, it appears that there are recognizable differences between the northern and southern subtropical faunas, as well as between the central Pacific equatorial and subtropical faunas.

\section{Solution-Susceptible Species}

Reports on solution susceptibility of Cretaceous planktonic foraminifers (Sliter, 1972, 1976; Douglas, 1971; Caron, 1975; Olsson, 1964) are conflicting. The globotruncanids, heavily ornamented heterohelicids, Abathomphalus, Gublerina, rugoglobigerinids, and "Gtr." havanensis are reported to be solution-resistant, whereas hedbergellids, Gtr. cretacea, Globigerinelloides spp., Guembelitria, smoother heterohelicids, and non-keeled juveniles are most solution-susceptible. Nevertheless, Caron (1975) reported Maastrichtian dissolved faunas containing only hedbergellids, Globigerinelloides, and heterohelicids from the central Pacific.

At Site 465, dissolved faunas include concentrations of $H$. globulosa, $R$. rugosa, P. glabrata, $H$. pulchra, Gtr. arca, Gtr. stuartiformis, H. striata, Psg. costulata, $H$. navarroensis, and Gtr. tricarinata $(12-1,60 \mathrm{~cm})$. In 12, CC, both Gtr. arca and Gtr. stuartiformis are concentrated by dissolution, and in 19-3 Gtr. fornicata and H. striata occur in abundance with Gtr. stuartiformis and Gtr. tricarinata. In the dissolved zone below the Cretaceous/Tertiary boundary, Psg. excolata is sometimes the only species present. In one very heavily dissolved sample, Gtr. havanensis is concentrated.

\section{BENTHIC-FORAMINIFER PALEOECOLOGY}

Benthic-foraminifer populations were identified at selected intervals through the Cretaceous at Sites 465 and 466. The faunas were compared to those identified by Sliter (1972, 1975, 1976), and paleoenvironments were assigned according to his criteria.

Albian to early Cenomanian faunas from this area consistently contain Gavelinella intermedia, Osangularia sp. ex. gr. O. utaturensis, Patellina australis, Praebulimina sp. (of Scheibnerova, 1974), and Neobulimina sp. (of Gradstein, 1978). Gavelinella intermedia is particularly abundant at Sites 463 and 465 ; the buliminids appear in floods at Site 465 (34-1), and occasionally at Site 466 in the Albian. The faunas at Site 465 are generally low in diversity and high in dominance of the gavellinellids or buliminids. At Site 466, diversity is higher, and the gavellinellids less abundant.

At Site 465, Cenomanian benthic faunas are more diverse; rotalids continue to predominate in the faunas, but Praebulimina sp. is common to abundant at some 
levels. Addition of Anomalina, Bolivina, Gyroidinoides and several buliminids occurs in the Coniacian $(25, \mathrm{CC})$, and diversity increases markedly. By the Santonian, Nuttalides truempyi, Pullenia, pleurostomellids, and several lagenids occur in the faunas. Small buliminids occur abundantly throughout the section. Campanian faunas include two species of Aragonia, and by the Maastrichtian the buliminids, $N$. truempyi, A. velascoensis, G. beccariformis, Stilostomella, and the pleurostomellids are common. Uvigerina taurica first occurs in the " $G$." eugubina Zone of the earliest Paleocene.

A simple diagram representing the probable depositional depths at Site 465 is shown in Figure 10. This site bottoms in volcanic trachyte, overlain by sediments containing the benthic foraminifers mentioned above, and planktonic faunas containing individuals of $R$. apenninica which are very small; they may be juveniles from near-surface waters over the shelf area, or they may be smaller because of water chemistry. Accompanying sediments contain plant fibers, mollusk fragments, and clays interpreted as a turbidite. The most abundant benthic, $G$. intermedia, is reported from Albian slope-depth environments of Australia (Scheibnerova, 1974), the Blake Nose (Gradstein, 1978), Site 259 in the Indian

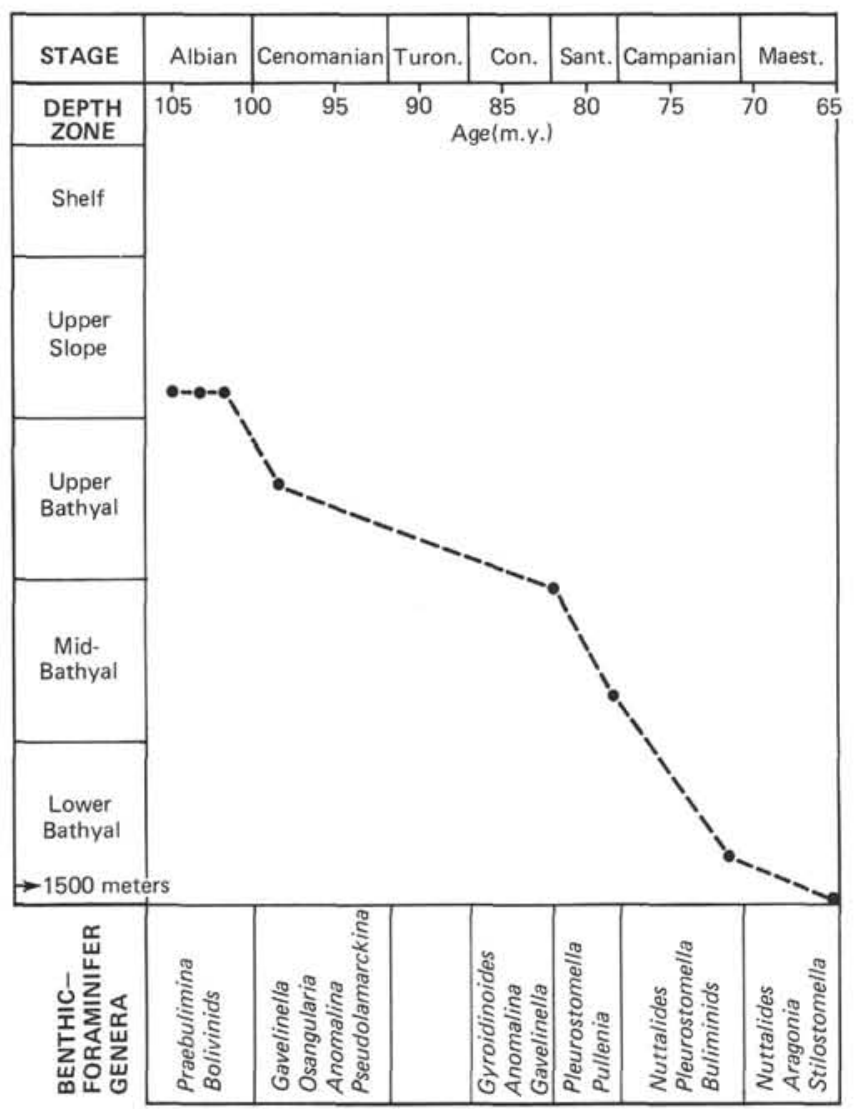

Figure 10. The relative depositional depth of Site 465 through the course of the late Cretaceous, as indicated by benthic-foraminifer faunas at the site. Dominant genera in samples through the Late Cretaceous are shown along the bottom of the diagram. The depth indications of these faunas are inferred from the scheme of Sliter (1976).
Ocean (Scheibnerova, 1974), the Falkland Plateau (Sliter, 1976), and the Shatsky Rise (Luterbacher, 1975).

Gradual deepening, as more genera are added, follows the scheme of Sliter (1976). By Maastrichtian time, the site lay close to its present depth.

\section{REFERENCES}

Blow, W. H., 1971. Deep Sea Drilling Project, Leg 6, foraminifera from selected samples. In Fischer, A. G., Heezen, B. C., et al., Init. Repts. DSDP, 6: Washington (U.S. Govt. Printing Office), 1013-1027.

Bolli, H. M., 1957. The genera Praeglobotruncana, Rotalipora, Globotruncana, and Abathomphalus in the Upper Cretaceous of Trinidad. Bull. U.S. National Mus., 215:51-60.

Caron, M., 1975. Late Cretaceous planktonic foraminifera from the northwest Pacific, Leg 32 of the DSDP. In Larson, R. L., Moberly, R., et al., Init. Repts. DSDP, 32: Washington (U.S. Govt. Printing Office), 710-724.

1978. Cretaceous planktonic foraminifera from Deep Sea Drilling Project 40, southeast Atlantic Ocean. In Bolli, H. M., Ryan, W. B. F., et al., Init. Repts. DSDP, 40: Washington (U.S. Govt. Printing Office), 651-678.

Douglas, R. G., 1971. Cretaceous foraminifera from the northwest Pacific Ocean: Leg 6, Deep Sea Drilling Project. In Fischer, A. G., Heezen, B. C., et al., Init. Repts. DSDP, 6: Washington (U.S. Govt. Printing Office), 1027-1053.

1973. Planktonic foraminifera biostratigraphy in the central North Pacific Ocean. In Winterer, E. L., Ewing, J. I., et al., Init. Repts. DSDP, 17: Washington (U.S. Govt. Printing Office), 673-675.

Fleischer, R. L., 1975. Oligocene planktonic foraminiferal biostratigraphy, central north Pacific Ocean, Deep Sea Drilling Project Leg 32. In Larson, R. L., Moberly, R., et al., Init. Repts. DSDP, 32: Washington (U.S. Govt. Printing Office), 753-765.

Gradstein, F., 1978. Biostratigraphy of lower Cretaceous Blake Nose and Blake-Bahama Basin foraminifera, DSDP Leg 44, western north Atlantic Ocean. In Benson, W. E., Sheridan, R. E., et al., Init. Repts DSDP, 44: Washington (U.S. Govt. Printing Office), 663-701.

Hardenbol, J., and Berggren, W. A., 1978. A new Paleogene numerical time scale. Am. Assoc. Petrol. Geol. Stud. Geol., 6:213-234.

Krashenninikov, V., 1971. Cenozoic foraminifera. In Fischer, A. G., Heezen, B. C., et al., Init. Repts. DSDP, 6: Washington (U.S. Govt. Printing Office), 1055-1079.

Lancelot, Y., and Larson, R., 1975. Sedimentary and tectonic evolution of the northwestern Pacific. In Larson, R. L., Moberly, R., et al., Init. Repts. DSDP, 32: Washington (U.S. Govt. Printing Office), 925-941.

Luterbacher, H., 1975. Paleocene and early Eocene planktonic foraminifera, Leg 32, Deep Sea Drilling Project. In Larson, R. L., Moberly, R., et al., Init. Repts. DSDP, 32: Washington (U.S. Govt. Printing Office), 725-735.

McNulty, C., 1976. Smaller Cretaceous foraminifera of Leg 43, Deep Sea Drilling Project. In Tucholke, B. E., Vogt, P. R., et al., Init. Repts. DSDP, 43: Washington (U.S. Govt. Printing Office), 487-504.

Olsson, R. K., 1964. Late Cretaceous planktonic foraminifera from New Jersey and Delaware. Micropaleont., 10:157-188.

Pessagno, E. A., 1960. Stratigraphy and micropaleontology of the Cretaceous and lower Tertiary of Puerto Rico. Micropaleont., $6: 1-18$

1962. The upper Cretaceous stratigraphy and micropaleontology of the Cretaceous and lower Tertiary of Puerto Rico. Micropaleont., 8:349-368.

Said, R., and Kenawy, A., 1956. Upper Cretaceous and Lower Tertiary foraminifera from northern Sinai, Egypt. Micropaleont., 2:105-173.

Scheibnerova, V., 1974. Aptian-Albian benthonic foraminifera from DSDP Leg 27, Sites 259, 260, and 263, eastern Indian Ocean. In Veevers, J. J., Heirtzler, J. R., et al., Init. Repts. DSDP, 27: Washington (U.S. Govt. Printing Office), 679-741.

Sliter, W. V., 1972. Cretaceous foraminifers-depth habitats and their origin. Nature, 239:514-515. 


\section{A. BOERSMA}

1975. Foraminiferal life and residue assemblages from Cretaceous slope deposits. Geol. Soc. Am. Bull., 86:897-906.

1976. Cretaceous foraminifers from the southwestern Atlantic Ocean, Leg 36, Deep Sea Drilling Project. In Barker, D. F., Dalziel, I. W. D., et al., Init. Repts. DSDP, 36: Washington (U.S. Govt. Printing Office), 519-545.
Toumarkine, M., 1975. Middle and late Eocene planktonic foraminifera, from the northwestern Pacific, Leg 32 of the Deep Sea Drilling Project. In Larson, R. L., Moberly, R., et al., Init. Repts. DSDP, 32: Washington (U.S. Govt. Printing Office), 735-753. van Hinte, J., 1976. A Cretaceous time-scale. Bull. Am. Assoc. Petrol. Geol., 60:498-516. 